\title{
BRUNO DE CRUDIS RODRIGUES
}

Estudo da expressão do transcrito regulado pela cocaína e anfetamina (CART) no encéfalo de ratos durante o desenvolvimento pós-natal

Dissertação de Mestrado apresentada ao Instituto de Ciências Biomédicas da Universidade de São Paulo, para obtenção do Título de Mestre em Ciências Morfofuncionais. 


\section{BRUNO DE CRUDIS RODRIGUES}

Estudo da expressão do transcrito regulado pela cocaína e anfetamina (CART) no encéfalo de ratos durante o desenvolvimento pós-natal

Dissertação de Mestrado apresentada ao Instituto de Ciências Biomédicas da Universidade de São Paulo, para obtenção do Título de Mestre em Ciências.

Área de concentração: Anatomia

Orientadora: Profa. Dra. Carol Fuzeti Elias 


\section{DADOS DE CATALOGAÇÃO NA PUBLICAÇÃO (CIP)}

Serviço de Biblioteca e Informação Biomédica do Instituto de Ciências Biomédicas da Universidade de São Paulo

reprodução não autorizada pelo autor

\section{Rodrigues, Bruno de Crudis.}

Estudo da expressão do transcrito regulado pela cocaína e anfetamina (CART) no encéfalo de ratos durante $o$ desenvolvimento pós-natal / Bruno de Crudis Rodrigues. -- São Paulo, 2008.

Orientador: Carol Fuzeti Elias.

Dissertação (Mestrado) - Universidade de São Paulo. Instituto de Ciências Biomédicas. Departamento de Anatomia. Área de concentração: Ciências Morfofuncionais. Linha de pesquisa: Análise neuroquímica e funcional dos sistemas neurais.

Versão do título para o inglês: Study of the expression of cocaine- and amphetamine- regulated transcript (CART) in the rat forebrain during post-natal development.

Descritores: 1. Neuroanatomia 2. Neurociência 3. Neuroquímica I. Elias, Carlos Fuzeti II. Universidade de São Paulo. Instituto de Ciências Biomédicas. Programa de Pós Graduação em Ciências Morfofuncional III. Título. 
Candidato(a):

Título da Dissertação:

Orientador(a):
Bruno de Crudis Rodrigues.

Estudo da expressão do transcrito regulado pela cocaína e anfetamina (CART) no encéfalo de ratos durante o desenvolvimento pós-natal.

A Comissão Julgadora dos trabalhos de Defesa da Dissertação de Mestrado, em sessão pública realizada a .... ...
( ) Aprovado(a)
( ) Reprovado(a)

Examinador(a): Assinatura:

Nome:

Instituição:

Examinador(a): Assinatura:

Nome:

Instituição:

Presidente: Assinatura:

Nome:

Instituição: 


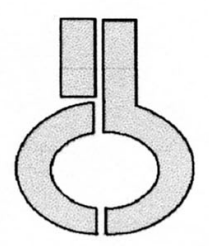

\section{Certificado}

Certificamos que o protocolo registrado sob $n^{\circ} 021$ nas fls. 29 do livro 2 para uso de animais em experimentação, sob a responsabilidade do(a) Prof.(a) Dr.(a) Carol Fuzeti Elias, Coordenador(a) da Linha de Pesquisa "Estudo da expressão do transcrito regulado pela cocaina e anfetamina (CART) durante 0 desenvolvimento pós-natal em núcleos prosencefálicos" do qual participou(aram) o(s) alunos Bruno de Crudis Rodrigues, está de acordo com os Princípios Éticos de Experimentação Animal adotado pelo Colégio Brasileiro de Experimentação Animal (COBEA) e foi aprovado pela COMISSÃO DE ÉTICA EM EXPERIMENTAÇÃO ANIMAL (CEEA) em 23.02.2006.

São Paulo, 06 de março de 2006.

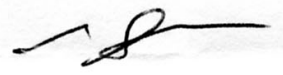

Profa. Dra. Marília C.L.Seelaender Coordenadora -CEEA - ICB/USP

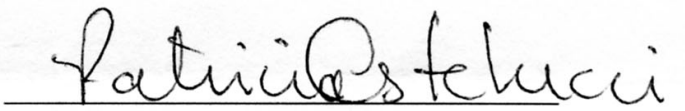

Profa. Dra. Patricia Castelucci Secretária Suplente CEEA - ICB/USP 
À minha amada, Gabriela Altero Bispo, que esteve sempre ao meu lado

Dedico. 


\section{AGRADECIMENTOS}

À natureza, mãe criadora.

À minha família, que sempre me apoiou em minhas decisões.

À minha orientadora, que teve paciência e muito cuidado para me ensinar o "bê-a-bá" de tudo o que fiz durante a minha iniciação científica e mestrado, e por ser um exemplo admirável de ser humano.

Ao professor Jackson Cioni Bittencourt, que sempre encontrava um tempinho para tirar dúvidas no microscópio, mesmo ele tendo me assustado dizendo que o indusium griseum não era o indusium griseum!

À todos os professores, funcionários e colegas do departamento, que de alguma forma colaboraram para o desenvolvimento desse trabalho.

À todos os integrantes do laboratório de neuroanatomia química pela convivência e eventuais colaborações técnicas e/ou intelectuais.

Ao Dr Joel Elmquist, pela sonda para o RNAm de CART, ferramenta chave para este trabalho.

À Universidade Presbiteriana Mackenzie, em especial à professora Miriam Ribeiro de Oliveira.

Aos amigos, que mesmo de fora, deram sugestões em como lidar com as mais distintas situações.

À Joana, minha querida bicicleta, que me trouxe para o laboratório tantas vezes ao longo do desenvolvimento deste trabalho, me privando do estresse do trânsito e dos ônibus lotados.

À FAPESP pelo suporte financeiro. 
"Tudo aquilo de que precisamos para começar é um sonho de que podemos fazer melhor do que fizemos até aqui. Só precisamos ter fé e agir."

Carl Sandrug

"Para ser grande, sê inteiro: nada Teu exagera ou exclui.

Sê todo em cada coisa.

Põe quanto és

No mínimo que fazes.

Assim em cada lago a lua toda Brilha, porque alta vive." 


\section{RESUMO}

Rodrigues BC. Estudo da expressão do transcrito regulado pela cocaína e anfetamina (CART) no encéfalo de ratos durante o desenvolvimento pós-natal [Dissertação]. São Paulo: Instituto de Ciências Biomédicas da Universidade de São Paulo; 2008.

O transcrito regulado pela cocaína e anfetamina (CART) é amplamente expresso em todo o sistema nervoso central. Ele está envolvido na manutenção de diversas funções neurofisiológicas como comportamento alimentar, comportamento sexual, memória e aprendizagem, controle do estresse, processos sensoriais e plasticidade neuronal. Evidências sugerem que o CART deve participar de processos relacionados ao desenvolvimento neural. Diante disso estudamos a expressão do CART em diferentes idades pós-natais com o intuito de identificar as possíveis regiões prosencefálicas nas quais este peptídeo pode estar participando do desenvolvimento neuronal. Por meio da técnica de hibridização in situ, comparamos a expressão do CART no prosencéfalo de animais de 6, de 26 e de 66 dias de vida. Observamos que os animais de 6 dias expressam uma maior quantidade de CART em várias regiões prosencefálicas comparado com animais jovens (26 dias) e adultos (66 dias). Estas áreas são: o córtex somatossensorial, o córtex piriforme, o indusim griseum, o giro denteado, o núcleo accumbens e o núcleo pré-mamilar ventral. Observamos também que o CART é expresso nos núcleos ventro-póstero lateral e ventro-póstero medial do tálamo nos animais de 6 dias, expressão que não é observada no animal adulto. Em outras regiões como o CA1 e o núcleo arqueado não observamos diferença. Utilizando imunohistoquímica, observamos que o peptídeo CART está presente nas regiões descritas. Nossos dados sugerem que o CART participa de processos relacionados ao desenvolvimento em diversas regiões do prosencéfalo.

Palavras chave: CART; Desenvolvimento; Peptídeo; Prosencéfalo. 


\begin{abstract}
Rodrigues BC. Study of the expression of cocaine- and amphetamine- regulated transcript (CART) in the rat forebrain during post-natal development [Master thesis]. São Paulo: Instituto de Ciências Biomédicas da Universidade de São Paulo; 2008.

Cocaine and amphetamine-regulated transcript (CART) is found widespread in the rodent nervous system. It has been involved in many different functions including feeding and sexual behaviors, learning and memory, stress responses, sensory processing and neuronal plasticity. Recent studies suggest that CART may be also implicated in neural development. Therefore, in the present study we investigated CART expression in the forebrain of rats in different stages of development. Using in situ hybridization, we compared CART expression in the forebrain of 6, 26 and 66 days old Sprague-Dawley rats. In general, we found a higher expression of CART in 6 days old animals comparing to other groups. Specifically, we found increased CART expression in the somatosensory and piriforme cortex, induzium griseum, dentate gyrus, nucleus accumbens, and ventral prepamammillary nucleus. Interestingly, we found CART expression in the ventral posteromedial and ventral posterolateral thalamic nuclei only in 6-days old animals. In other regions including the CA1 and the arcuate nucleus, CART expression did not change. By using immunohistochemistry we found that the CART peptide is produced in the areas where we found the mRNA, in 6 days old animals. Our findings suggest that the CART participate in neural development in various forebrain nuclei.
\end{abstract}

Key words: CART; Development; Peptide; Forebrain. 


\section{SUMÁRIO}

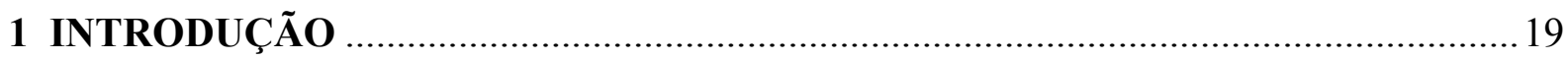

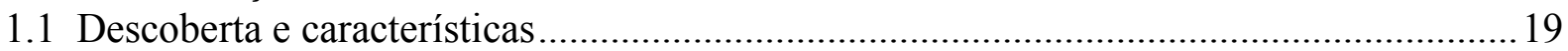

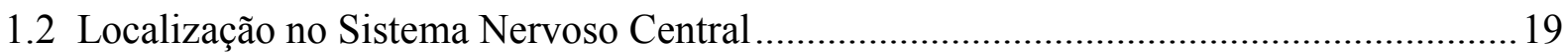

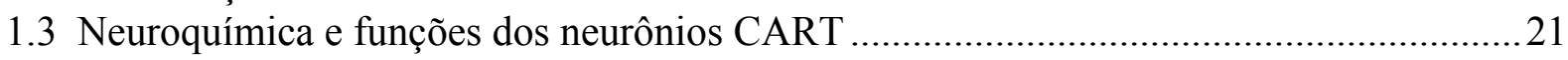

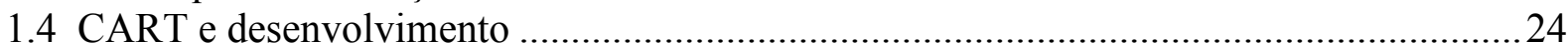

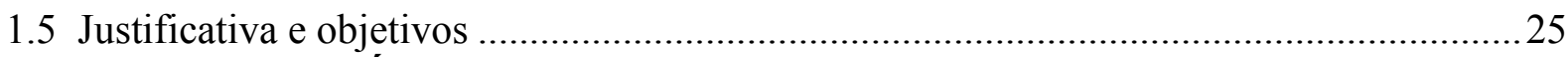

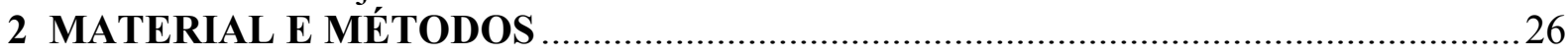

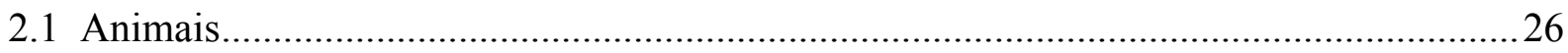

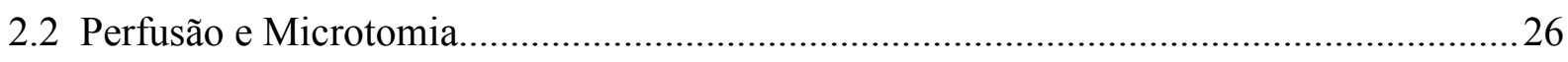

2.3 Método de Nissl para o Estudo da Citoarquitetura...........................................................26

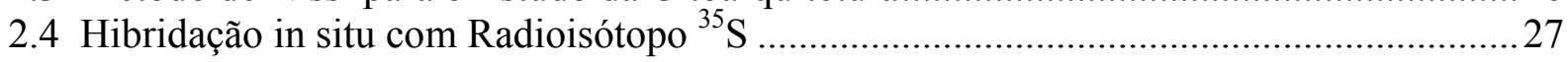

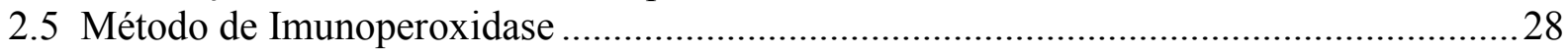

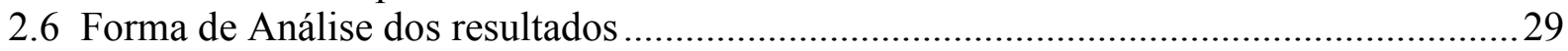

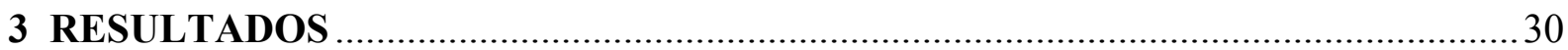

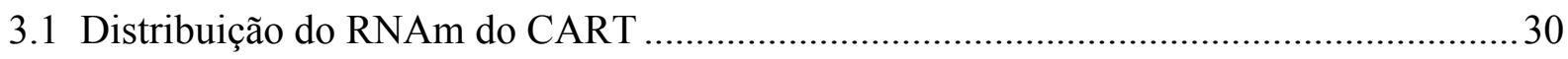

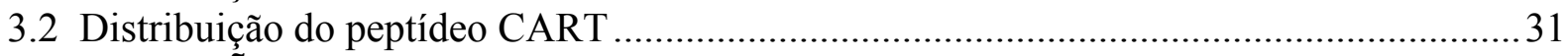

4 DISCUSSÃ̃

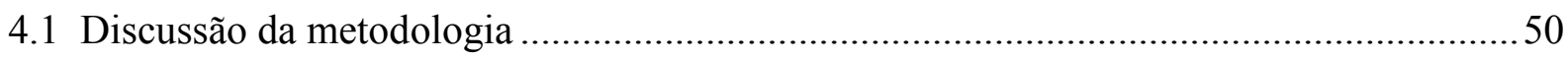

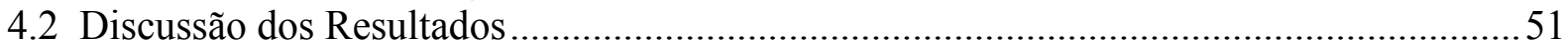

5 CONCLUSÕES

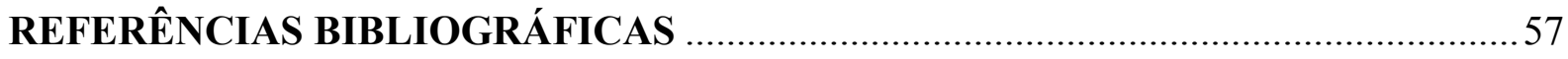




\section{INTRODUÇÃO}

\subsection{Descoberta e características}

Com o intuito de identificar novos genes responsivos à administração de drogas psicomotoras (cocaína e anfetamina) Douglass e colaboradores (1995) isolaram e observaram o RNA total de algumas regiões do encéfalo de ratos e notaram que havia um gene que era de 4 a 5 vezes mais expresso no striatum de animais submetidos a doses agudas de cocaína ou anfetamina. Nessas condições, foi dado o nome de transcrito regulado pela cocaína e anfetamina (CART) para o que seria um possível neurotransmissor envolvido em mecanismos das vias de controle de reforço e recompensa relacinados à drogas de abuso. Embora Douglass tenha sido o primeiro a descrever tal gene, anos antes Spiess e colaboradores (1981) haviam observado em extrato de hipotálamo de ovelhas, a existência de uma seqüência de aminoácidos desconhecidos até então. Essa sequência de aminoácidos fazia parte do que mais tarde seria chamado de CART.

Existem duas formas do peptídeo CART em roedores, uma com 116 aminoácidos e outra com 129 aminoácidos. A forma mais curta é a mais estudada e é duas vezes mais abundante. Em humanos, somente a forma mais curta é encontrada. Estudos sugerem que o CART é secretado e processado logo após sua utilização. Pesquisadores também têm estudado o CART em humanos e observaram que seu cDNA CART é $80 \%$ idêntico ao cDNA de rato com 92\% de homologia na região que codifica peptídeo CART (Adams et al., 1999).

\subsection{Localização no Sistema Nervoso Central}

No mesmo trabalho em que descreveu o RNAm em questão como um transcrito regulado pela cocaína e anfetamina, Douglass e colaboradores (1995) também fizeram um primeiro estudo neuroanatômico da distribuição deste RNAm. Suas primeiras observações revelaram que a região de maior síntese de CART é o hipotálamo e que este apresenta a mais extensa distribuição de marcações entre as regiões estudadas. Veremos isso detalhadamente à diante. O telencéfalo, que abriga o striatum, onde há variação da expressão de CART com administração aguda de drogas psico-motoras, também apresenta outras regiões com 
expressão. A porção ventral do striatum (constituída pelo núcleo accumbens e o tubérculo olfatório), o córtex somatosensorial primário e o córtex piriforme apresentaram expressão moderada. $\mathrm{O}$ indusium griseum foi descrito como umas das regiões de mais intensa expressão de todo o encéfalo. Expressão moderadamente baixa foi observada no núcleo intersticial da estria terminal (BST) e no giro denteado do hipocampo rostral. O complexo amigdalóide foi descrito com expressão moderadamente alta, finalizando o telencéfalo. No hipotálamo, células com marcações intensas para moderadas foram observadas nos núcleos paraventricular porção parvocelular, arqueado, e supra óptico. Também houve células espalhadas, com marcação intensa para moderada, nas regiões perifornicial, no hipotálamo posterior e na área hipotalâmica lateral. Marcações moderadas foram descritas na porção posterior do núcleo periventricular, nos núcleos mamilar medial, pré-mamilar ventral e na porção lateral do núcleo supra-mamilar. Nó tálamo, Douglass e colaboradores observaram marcação de RNAm moderada para baixa em porções mediais da zona incerta, na porção ventral do núcleo reuniens e nas habênulas laterais. Apesar de ter sido umas das regiões com menor numero de células marcadas, o mesencéfalo contém um dos núcleos com a mais intensa marcação observada, o núcleo de Edinger Westphal. Além deste núcleo, foram observadas marcações moderadamente baixas em células espalhadas na substancia cinzenta periaqueductal dorsal. $\mathrm{O}$ rombencéfalo também foi descrito e apresenta regiões com células que expressam CART como o núcleo olivar inferior e o núcleo do trato solitário que apresentaram marcação moderada, e como o locus coeruleus e o núcleo incerto que apresentaram pouca marcação, além de algumas células espalhadas por regiões do núcleo ambíguo que também apresentaram marcação moderada.

Em um trabalho subsequente ao de Douglass, Couceyro e colaboradores (1997) complementaram as análises sobre distribuição anatômica da expressão do CART. Suas observações, além de confirmarem as descrições anteriores, acrescentaram informações sobre o CART tanto no sistema nervoso central, quanto fora deste. Fazendo parte do sistema nervoso, foram acrescentadas algumas regiões como a retina, as células mitrais e as células da lâmina externa da camada plexiforme do bulbo olfatório, regiões somatossensoriais do córtex cerebral, a medula espinal que apresentou células marcadas nos níveis cervicais e toráxicos próximo ao canal central.

Com o desenvolvimento de anticorpos o peptídeo CART também passou a ser estudado. De forma geral, as regiões que haviam sido descritas anteriormente também apresentaram imunorreatividade ao peptídeo CART (CART-ir) (Koylu et al., 1997 e 1998). Koylu e colaboradores (1997) deram especial atenção ao hipotálamo e observaram que 
diversas regiões apresentaram CART-ir, dentre elas estão o núcleo supra-óptico, o paraventricular, o periventricular, o núcleo arqueado, a área hipotalâmica lateral, a zona incerta e o núcleo pré-mamilar ventral.

1.3 Neuroquímica e funções dos neurônios CART

Usando técnicas de dupla marcação, diversos pesquisadores passaram a investigar a neuroquímica dos neurônios que expressam CART. Elias e colaboradores (1998) demonstraram haver co-expressão tanto do RNAm quanto do peptídeo CART com o RNAm da pró-opiomelanocortina (POMC) em neurônios do núcleo arqueado e na área retroquiasmática. A POMC é uma molécula percursora de outros peptídeos bioativos: os opióides, as melanocortinas e corticotropinas. O gene POMC é expresso em diversos tecidos tais como o hipotálamo, a hipófise, o sistema imunológico e a pele. A molécula POMC sofre clivagens de acordo com as enzimas presentes em cada tecido, originando os diferentes peptídeos (Bertagna, 1994; Castro e Morrison, 1997; Smith e Blalock, 1981). Entre as melanocortinas, a mais estudada é o hormônio estimulante de melanócitos ( $\alpha-\mathrm{MSH})$, ele é produzido nos núcleos arqueado e do trato solitário, e reconhecido como inibidor do comportamento alimentar (Fan et al., 1997). Os neurônios do núcleo arqueado que coexpressam POMC e CART também expressam o receptor para leptina, de forma longa $(\mathrm{OBRb})$, que é seu receptor de membrana responsável pela sinalização intra-celular (Elmquist et al., 1998). A leptina é um hormônio secretado pelo tecido adiposo branco, que informa ao sistema nervoso sobre as reservas energéticas do indivíduo, dentre outras maneiras, estimulando diretamente os neurônios do núcleo arqueado acima mencionados (Zhang et al., 1994 ;Cowley et al., 2001; Elias et al., 2001). O núcleo dorso-medial do hipotálamo, o prémamilar ventral e a área retroquiasmática também co-expressam CART e OBRb. Além disso, os neurônios CART de núcleos hipotalâmicos como o arqueado, o dorso-medial do hipotálamo e o pré-mamilar ventral também apresentam marcações que indicam ativação celular em resposta à administração de leptina como o RNAm do sinalizador do supressor de citocina (SOCS-3) e imunorreatividade à proteína Fos (Fos-ir). Esses resultados demonstram que grande parte dos neurônios CART hipotalâmicos são influenciados diretamente pela leptina (Elias et al., 2000). No núcleo arqueado, por exemplo, os níveis de CART são influenciados pela quantidade de leptina circulante. Em animais deficientes a leptina ou seu 
receptor $(\mathrm{OBRb})$, ou ainda, em animais em jejum (estado que diminui a concentração de leptina endógena), os níveis de CART no núcleo arqueado são reduzidos (Kristensen et al., 1998).

Outra molécula que se relaciona com o CART é o hormônio concentrador de melanina $(\mathrm{MCH})$. Eles se co-localizam em neurônios da zona incerta, da área hipotalâmica lateral, do núcleo periventricular do hipotálamo e, em menor número, no núcleo dorso-medial do hipotálamo. $\mathrm{O} \mathrm{MCH}$ é um neuropeptídeo orexigênico inicialmente descrito em hipófise de peixes como um regulador de mudanças na cor da pele (Nahon, 1994). Atualmente, ele é estudado por sua participação em diversos mecanismos neurofisiológicos envolvidos com o comportamento alimentar, com memória e aprendizado, comportamentos motivados, mecanismos sensoriais, entre outros (Monzon et al., 1999; Gonzáles et al., 1996; Miller et al., 1993). Injeções intracerebroventriculares (icv) de MCH em camundongos aumentam o consumo alimentar ao mesmo passo que diminuem o gasto energético. Ainda, injeções locais nos núcleos paraventrícular do hipotálamo, arqueado e dorso-medial do hipotálamo induzem comportamento alimentar. Animais deficientes em leptina (ob/ob), alimentados ou em jejum, apresentam expressão aumentada do RNAm do $\mathrm{MCH}$. Indivíduos deficientes em $\mathrm{MCH}$ ou seu receptor (MCH1-R) são resistentes à obesidade induzida por dieta altamente calórica (Ludwig et al., 2001).

Os neurônios CART do núcleo paraventrícular do hipotálamo e do núcleo supraóptico também expressam a sintase do óxido nítrico neuronal (nNOS). A nNOS é observada em grande quantidade em núcleos hipotalâmicos indicando atividade do óxido nítrico (NO) nos mesmos. No paraventricular ele está envolvido com o comportamento sexual e alimentar, e no supra-óptico com o comportamento alimentar. Estudos demonstraram que os neurônios CART são estimulados pelo NO. Tanto o CART quanto o NO apresentam-se diminuídos em animais em jejum, e em ambos os casos esse controle é feito através da leptina (Koylu et al., 2000; Ahima et al., 1999; Isse et al., 1999).

Neurônios CART também expressam RNAm de prodinorfina (proDYN) na porção magnocelular do núcleo paraventricular do hipotálamo, no núcleo supra-óptico, na área retroquiasmática, no núcleo arqueado, e no accumbens (Elias et al, 2001, Hubert e Kuhar, 2006). A dinorfina (DYN) é antagonista de receptores opióides, apesar de também interagir com outros peptídeos não-opióides e com aminoácidos excitatórios. Está amplamente distribuída no sistema nervoso central e tem sido estudada, entre outros motivos, por estar relacionada com processos cognitivos, em especial aqueles ligados ao desenvolvimento/envelhecimento. Seu envolvimento com aprendizagem e memória está 
relacionado com sua habilidade de inibir processos de plasticidade neuronal em diferentes tipos neuronais do giro denteado do hipocampo (Chavkin et al., 1982; Chen et al., 1995 a; Chen et al., 1995 b; Chen et al., 1998; Tang et al., 1999; Terman et al., 2000; Terman et al., 1994; Wagner et al., 1993).

Pesquisadores descreveram a co-localização do CART com o RNAm do hormônio liberador de tirotropina (TRH) na porção parvocelular do núcleo paraventricular, no periventricular anterior e posterior, no núcleo arqueado, e no dorsomedial do hipotálamo (Elias et al., 2001). Em outros trabalhos, autores observaram axônios CART-ir inervando a maioria dos neurônios TRH hipofisiotrópicos (neurônios reguladores da hipófise) no paraventricular do hipotálamo. O TRH é um tripeptídeo que se encontra espalhado por todo o sistema nervoso central. No paraventricular do hipotálamo, mais especificamente, nas subdivisões periventricular e medial da porção parvocelular do paraventricular, há neurônios TRH com funções hipofisiotrópicas com importantes funções na regulação do eixo hipotálamo-hipófise-tireóide. O TRH liberado por neurônios hipofisiotrópicos tem como função controlar a produção e liberação do hormônio estimulador da tireóide (TSH) e a secreção de prolactina (Lechan, 1993; Lechan \& Segerson, 1989; Fekete et.al., 2004; Kawano H et.al, 1991; Merchenthaler et al., 1994; Freeman et.al, 2000). Experimentos com injeção i.c.v. demonstraram que o CART é um potente estimulador da expressão do RNAm do TRH em neurônios hipofisiotrópicos de animais em jejum (Fekete et al., 2000).

Elias e colaboradores (2001) identificaram neurônios CART co-localizados com a descarboxilase do ácido glutâmico (GAD-67) nos seguintes núcleos hipotalâmicos: periventricular, núcleo arqueado, zona incerta, área hipotalâmica lateral e dorso-medial do hipotálamo. A GAD-67 atua na síntese do neurotransmissor ácido-gama-aminobutírico (GABA). Há neurônios GABAérgicos espalhados por todo o sistema nervoso central entre outros tecidos. Ele é bastante presente em interneurônios com caráter inibitório na medula espinal, no cerebelo, no hipocampo, no bulbo olfatório na retina entre outros (Kandel, 2000). Foi observado que CART e neurotensina (NT), no que se refere ao hipotálamo, se colocalizam somente no núcleo arqueado, e em poucos neurônios (Elias et al., 2001). A NT é um peptídeo com ampla distribuição no sistema nervoso central e em alguns tecidos periféricos. Este peptídeo faz parte de uma família de peptídeos envolvidos em diversas atividades biológicas, dentre elas: hipotermia, hipotensão e regulação na hipófise anterior (Elliot et al., 1986; Nemeroff et al., 1983; McCann et al., 1982; Frohman et al., 1982). Os corpos celulares de neurônios imunorreativos à neurotensina (NT-ir) são mais encontrados em 
áreas relacionadas ao sistema límbico do prosencéfalo, como o hipotálamo, o hipocampo e a amígdala (Jennes et al., 1982; Hara et al., 1982).

Apesar de estar co-localizado com diversos neurotransmissores, como vimos até agora, o CART não parece estar diretamente relacionado com as principais funções conhecidas de tais moléculas. Um exemplo disso é o fato de haverem neurônios CART/MCH na área hipotalâmica lateral e neurônios CART/POMC no núcleo arqueado. Como descrito acima, o MCH é um estimulador do comportamento alimentar, e peptídeos derivados da molécula POMC são inibidores do comportamento alimentar. Induzindo-nos a pensar que deve haver algum outro tipo de controle sendo feito pelo CART nesses neurônios.

\subsection{CART e desenvolvimento}

Há evidências de que o CART possa participar de processos relacionados com desenvolvimento de estruturas nervosas em diferentes âmbitos. Louis (1996), trabalhando com culturas de células, demonstrou que a proteína CART apresenta propriedades neurotróficas em diversas culturas primárias de células nervosas. Estão entre essas: células nervosas dopaminérgicas, células hipocampais, células da retina e de motoneurônios. Entre os efeitos atribuídos ao peptídeo CART nessas regiões estão o aumento da captação de dopamina, o prolongamento da vida neuronal e das ramificações neuronais. Outros pesquisadores demonstraram também in vitro a capacidade do CART em inibir a liberação de dopamina na fenda sináptica (Brunetti et al., 2000).

A ação específica do CART em neurônios hipotalâmicos não é conhecida, mas é importante ressaltar sua co-localização com neurônios que expressam o receptor de leptina (Elias et al., 2001). Estudos recentes têm sugerido a ação da leptina no desenvolvimento de vias hipotalâmicas, relacionadas ao controle do balanço energético. Neurônios dessa via coexpressam CART e OBRb (Bouret e Simerly, 2004; Elias et al., 2000). Durante o desenvolvimento pós-natal, quando o consumo de alimentos é exacerbado, os níveis de leptina se mantêm altos, tanto em ratos como em camundongos. O tratamento com leptina exógena nestes animais, não resulta em qualquer alteração no consumo ou no gasto energético, indicando a ocorrência de insensibilidade à leptina no que diz respeito ao controle da composição corpórea, e uma possível ação sobre o desenvolvimento cerebral (Devaskar et al., 1997; Ahima et al., 1998; Prouxl et al., 2001). Camundongos com ausência de leptina 
$(o b / o b)$ apresentam deficiência na expressão de proteínas neuronais e gliais, e o tratamento destes camundongos no período neonatal com leptina induz a expressão de proteínas relacionadas ao crescimento neuronal e formação de sinapses como a GAP-43, a sinaptofisina e a SAP-25 (Ahima et al., 1999; Steppan \& Swick, 1999).

\subsection{Justificativa e objetivos}

Considerando que animais deficientes em leptina apresentam diminuição da expressão de CART em neurônios hipotalâmicos, e que alguns desses neurônios dependem da leptina para seu desenvolvimento, e diante ainda das diversas evidências relacionando o CART a processos moduladores de plasticidade e morfologia neuronal expostas acima, levantamos a hipótese de que o CART deve participar do desenvolvimento de diversas regiões prosencefálicas.

Diante do exposto, nosso objetivo é investigar a expressão do CART no prosencéfalo de ratos em diferentes fases do desenvolvimento pós-natal. Nosso intuito é identificar as possíveis regiões nas quais o CART possa desempenhar papel no desenvolvimento do sistema nervoso. 


\section{MATERIAL E MÉTODOS}

\subsection{Animais}

Foram utilizados como animais experimentais ratos albinos (Sprague-Dawley), machos de 6, 26 e 66 dias. Os animais foram criados no Biotério de Experimentação do Departamento de Anatomia, com acesso à água e comida ad libitum, temperatura controlada $\left(21 \pm 1^{\circ} \mathrm{C}\right)$ e ciclo de claro/escuro de 12:12 horas com as luzes sendo acesas às 7:00 horas. Todos os procedimentos foram aprovados pela Comissão de Ética em Experimentação Animal do Instituto de Ciências Biomédicas da USP (protocolo n ${ }^{\circ}$ 106/04/CEEA).

\subsection{Perfusão e microtomia}

Sob anestesia com um coquetel contendo acepromazina $(0,2 \mathrm{mg} / \mathrm{mL})$ (Univet), xilazina $(5 \mathrm{mg} / \mathrm{mL})$ (Bayer) e quetamina $(1 \mathrm{mg} / \mathrm{mL})$ (Virbac), os animais passaram por perfusão transcardíaca. Para animais de 26 e 66 dias a perfusão foi iniciada com solução salina $0,9 \%(100 \mathrm{~mL})$ e a seguir a solução fixadora composta por $4 \%$ de paraformaldeído (LabSynth) e 3,8\% de tetraborato de sódio (bórax, LabSynth), pH 9,5 (1 L em 25 minutos). Os animais de 6 dias foram perfundidos com a mesma solução fixadora, mas com volume e tempo menor (100 mL em 10 minutos). Os encéfalos foram dissecados e permaneceram em solução crioprotetora (20\% de sacarose em DEPC-PBS para animais de 26 e 66 dias e $20 \%$ de sacarose em solução fixadora para animais de 6 dias) por aproximadamente 18 horas (“overnight") em seguida foram seccionados no plano frontal em micrótomo de congelação (animais de 26 e 66 dias) ou criostato (animais de 6 dias), na espessura de $30 \mu \mathrm{m}$ divididos em 5 (animais de 26 e 66 dias) ou 3 séries (animais de 6 dias).

2.3 Método de Nissl para o Estudo da Citoarquitetura

Uma série de cada animal foi submetida ao método de coloração de Nissl, utilizando tionina como corante, para que pudéssemos realizar o estudo da citoarquitetura das áreas de 
interesse. A coloração de Nissl foi realizada da seguinte forma: desidratação dos cortes em concentrações crescentes de álcoois etílicos (50\% - 70\% - 2 vezes 95\% - 3 vezes 100\%; 3 minutos cada) sendo posteriormente deslipidificados em xilol (Merk; 2 vezes de 3 minutos). Os cortes foram, então, reidratados em concentrações decrescentes de álcool etílico, colocados por 20 segundos na solução de tionina a $0,25 \%$, mergulhados 10 vezes em água destilada e novamente desidratados e deslipidificados (na mesma seqüência acima descrita), sendo finalmente cobertos com lamínula utilizando como meio de montagem o DPX (Aldrich).

\subsection{Hibridação in situ com Radioisótopo ${ }^{35} \mathrm{~S}$}

Os plasmídeos contendo os cDNAs para o peptídeo CART foram gentilmente cedidos pelo Prof. Dr. Joel K. Elmquist (University of Texas South Western Medical Center, Dallas TX-EUA). Os plasmídeos foram linearizados através da enzima de restrição Hind III conforme orientação do laboratório de origem, e isolados com Fenol-ClorofórmioIsoamilálcool. As sondas foram marcadas com ${ }^{35} \mathrm{~S}-\mathrm{UTP}$ através de transcrição in vitro no nosso laboratório, usando a enzima polimerase T3. As transcrições foram realizadas a $37^{\circ} \mathrm{C}$ por 1 hora e as sondas foram isoladas pela adição de $1 \mu \mathrm{L}$ de RNAsin e $1 \mu \mathrm{L}$ de RQ1 DNAse a $37{ }^{\circ} \mathrm{C}$ por dez minutos, e remoção dos NTPs não incorporados através de micro-colunas de resina (Probe Quant G-50). Realizado esse procedimento, foi feita a contagem de incorporação do ${ }^{35}$ S-UTP na sonda em aparelho de cintilação. A sonda foi utilizada à concentração de $10^{6} \mathrm{cpm} / \mathrm{mL}$ em tampão de hibridação previamente preparado, contendo sulfato de dextrana e 1× solução de Denhart. Em seguida foram acrescentadas ao tampão 750 $\mu \mathrm{L}$ de formamida $50 \%, 15 \mu \mathrm{L}$ de Lauril Sulfato $10 \%$ (SDS), $15 \mu \mathrm{L}$ de Tiosulfato de Sódio $10 \%$ e $30 \mu \mathrm{L}$ de 5 M DTT. A solução de hibridação contendo a sonda foi aplicada à superfície das lâminas contendo os cortes histológicos. As lâminas foram cobertas com lamínulas (Sigma) e deixadas em estufa de hibridação por aproximadamente 18 horas, a $56{ }^{\circ} \mathrm{C}$. No dia seguinte, as lamínulas foram retiradas, o tampão de hibridização foi lavado e o excesso de sonda foi retirado através de banhos em RNAase A $0,2 \%$ e de estringência (aumento de temperatura e diminuição na concentração de cloreto de sódio/citrato de sódio/SSC) para retirar as possíveis hibridações inexpecíficas. 
Após os banhos, as lâminas foram desidratadas em concentrações crescentes de álcool etílico e deixadas secar a temperatura ambiente. Em seguida foram transferidas para cassetes e, em sala escura, foram colocadas em contato com filme auto-radiográfico (Kodak- Biomax MR). Três dias depois o filme foi revelado com revelador (Kodak, 2min), água (banhos rápidos), fixador (Kodak, 2min) e água corrente. Verificada a incorporação da sonda pelo tecido as lâminas hibridizadas foram mergulhadas em emulsão auto-radiográfica (Kodak) e foram armazenadas em câmara fria a $4{ }^{\circ} \mathrm{C}$. Depois de aproximadamente 15 dias as lâminas foram reveladas com revelador (Kodak, $2 \mathrm{~min}$ ), água (10 mergulhos), fixador (Kodak, 2min) e água corrente (15min). As lâminas foram submetidas à contra-coloração pelo método de Nissl (descrito a cima).

\subsection{Método de Imunoperoxidase}

Utilizamos técnicas de imunohistoquímica pelo método do complexo avidinabiotina $(\mathrm{ABC})$ para a visualização do peptídeo CART nos animais de 6 dias. O tecido foi lavado com KPBS (duas vezes de 10min cada) e então recebeu um pré-tratamento com solução de peróxido de hidrogênio a 0,3\% em Triton X-100 0,3\% (Sigma) por 30min, para neutralização da peroxidase endógena. Após esse período, em temperatura ambiente, os cortes foram lavados em KPBS até serem retiradas todas as bolhas formadas. Depois, o tecido foi incubado em uma solução bloqueadora, contendo KPBS, Triton X-100 0,3\% e 3\% de soro normal de cabra (Vector Laboratories) por 1h, para inativar os sítios inespecíficos. O anticorpo anti-CART (Phoenix Pharmaceuticals Inc.) feito em coelho, numa concentração de 1:20.000 foi adicionado a esta mesma solução e deixados "overnight", a temperatura ambiente.

No dia seguinte, os cortes foram lavados duas vezes por 10min cada com KPBS e incubados com o anticorpo secundário biotinilado feito em burro anti-coelho (Jackson Laboratories) na concentração de 1:1.000, diluído em Triton X-100 a 0,3\% em KPBS, durante o período de $1 \mathrm{~h}$. Procedemos a novas lavagem com KPBS (2 vezes $10 \mathrm{~min}$ ) e incubação do tecido no complexo avidina-biotina (ABC - Vectastain Kit Elite, Vector) diluído em KPBS na concentração de 1:500, durante o período de $1 \mathrm{~h}$. Os cortes foram submetidos a duas lavagens de 10min cada com KPBS. A reação de imunoperoxidase foi realizada com 0,05\% diaminobenzidina (DAB - Sigma) e níquel sulfato 0,02\% como cromógenos e peróxido de hidrogênio $0,03 \%$. A reação foi interrompida com duas lavagens de $10 \mathrm{~min}$ cada 
em KPBS e os cortes foram montados em lâminas gelatinizadas. Posteriormente, o tecido foi submetido ao processo de desidratação (1 vez em álcool etílico a 50\%, 1 vez em álcool etílico a 70\%, 2 vezes em álcool etílico a 95\%, 3 vezes em álcool etílico absoluto, cada uma com duração de $3 \mathrm{~min}$ ). Os cortes foram então submetidos a dois banhos de xilol, 3min cada, seguidos da montagem das lâminas com lamínula e DPX (meio de montagem para lâminas permanentes, Aldrich).

\subsection{Forma de Análise dos resultados}

Os resultados obtidos foram analisados em microscópio de campo claro e campo escuro Leica, modelo DMR, com câmara fotográfica adaptada. As fotomicrografias foram montadas em pranchas utilizando o programa Photoshop CS, e apenas o balanço das cores, o brilho e o contraste foram ajustados (Saper, 1999). A variação da expressão do CART foi analisada inicialmente de forma subjetiva como mostra a Tabela-1 onde uma cruz indica uma baixa expressão, duas cruzes indicam expressão moderadamente baixa, três cruzes, expressão moderadamente alta, e quatro cruzes, expressão alta. Um traço (-) indica ausência de expressão. Posteriormente, as regiões que apresentaram aparente diferença foram quantificadas utilizando contagem da densidade óptica integrada (com pixels em tons de cinza variando de 0 a 255) através do software ImageProPlus. A realização das contagens foi feita com áreas pré-determinadas, de tamanhos constantes para cada região. Procuramos a melhor secção representativa para cada região (uma secção por animal) e, considerando as microestruturas, posicionamos a área pré-determinada sempre no mesmo local para obter a densidade óptica integrada. A quantificação foi então ajustada pela subtração da marcação de fundo do mesmo corte de cada contagem. Com as densidades ópticas integradas ajustadas realizamos, por fim, as análises estatísticas através do método de ANOVA e pós-teste de múltipla comparação de Newman-Keuls. Os gráficos e os cálculos estatísticos foram realizados utilizando o programa Graph Pad Prism V.3. 


\section{RESULTADOS}

\subsection{Distribuição do RNAm do CART}

Pudemos observar, que na maioria das regiões estudadas houve maior expressão de CART nos animais de 6 dias. Descreveremos abaixo, de forma detalhada, os resultados obtidos com a quantificação da expressão do CART.

Telencéfalo: no córtex somatossensorial primário, observamos expressão alta nos animais de 6 dias, expressão moderadamente baixa nos de 26 dias e expressão baixa nos animais de 66 dias (Fig. 1 e 2). Notamos também que a expressão ocorria nos limites das lâminas 3 e 4 . O córtex piriforme rostral apresentou expressão moderadamente alta nos animais de 6 dias, moderadamente baixa nos animais de 26 dias e expressão baixa nos animais de 66 dias (Fig. 3 e 4). De forma geral, a expressão apresentou-se constante para cada idade em toda extensão rostro-caudal do córtex piriforme. $\mathrm{O}$ indusium griseum apresentou expressão alta nos animais de 6 dias, e expressão moderadamente baixa tanto nos animais de 26 quanto nos de 66 dias (Fig. 5 e 6). No hipocampo, o campo CA1 apresentou expressão moderadamente baixa em todas as idades estudadas (Fig. 7 e 8), e o giro denteado apresentou expressão moderadamente alta nos animais de 6 dias, moderadamente baixa nos animais de 26 dias e baixa nos animais de 66 dias (Fig. 7 e 8). No accumbens, observamos expressão alta nos animais de 6 dias e expressão moderadamente baixa tanto nos animais de 26 quanto nos de 66 dias (Fig. 9 e 10).

Diencéfalo: No hipotálamo, o núcleo arqueado apresentou expressão aparente menor nos animais de 6 dias comparado com animais de 26 e 66 dias de idade (Fig. 11 e 12). No núcleo arqueado, no entanto, não observamos diferença estatística entre os grupos. O núcleo pré-mamilar ventral apresentou expressão alta em animais de 6 dias, moderadamente alta em animais de 26 dias e moderadamente baixa em animais de 66 dias (Fig. 13 e 14). No tálamo, observamos que houve expressão moderadamente alta nos animais de 6 dias na região dos núcleos ventro-póstero medial e ventro-póstero lateral (VPM e VPL). Em animais de 26 e 66 dias, não observamos expressão de CART nestes núcleos talâmicos (Fig. 15 e 16). 


\subsection{Distribuição do peptídeo CART}

Utilizamos a técnica de imunoperoxidase para verificar se o peptídeo CART estava sendo produzido nos animais de 6 dias. Observamos immunoreatividade ao peptídeo CART em várias regiões prosencefálicas descritas a seguir.

Telencéfalo: foram observadas células imunorreativas ao CART (CART-ir) no córtex somatossensorial primário (Fig. 17), na amígdala e no striatum. Ainda no telencéfalo foram observadas fibras CART-ir na fímbria do hipocampo (Fig. 17).

Diencéfalo: observamos células CART-ir nos núcleos ventro-pósteros laterais e mediais do tálamo (Fig. 17). Ainda no tálamo, observamos fibras CART-ir no núcleo ânterodorsal (Fig. 17). No hipotálamo observamos células CART-ir nos núcleos paraventricular e periventricular, na área hipotalâmica lateral, no núcleo arqueado, no núcleo pré-mamilar ventral (Fig. 17), no núcleo supra-mamilar e no hipotálamo posterior. 
Tabela 1: Análise subjetiva da expressão do transcrito regulado pela cocaína e anfetamina (CART) em regiões prosencefálicas em diferentes fases do desenvolvimento pós-natal $(6,26$ e 66 dias).

\begin{tabular}{|c|c|c|c|}
\hline Regiões prosencefálicas & 6 dias & 26 dias & 66 dias \\
\hline Cx Somatossensorial $1^{\circ}$ & ++++ & ++ & + \\
\hline Córtex Piriforme (rostral) & +++ & ++ & + \\
\hline Indusium Griseum & ++++ & ++ & ++ \\
\hline Giro Denteado & +++ & ++ & + \\
\hline Campo CA1 & ++ & ++ & ++ \\
\hline Accumbens & ++++ & ++ & ++ \\
\hline Núcleo arqueado & ++ & +++ & +++ \\
\hline Pré-mamilar Ventral & ++++ & +++ & ++ \\
\hline $\begin{array}{l}\text { Núcleos póstero-ventrais } \\
\text { do tálamo (VPM/VPL) }\end{array}$ & +++ & - & - \\
\hline
\end{tabular}




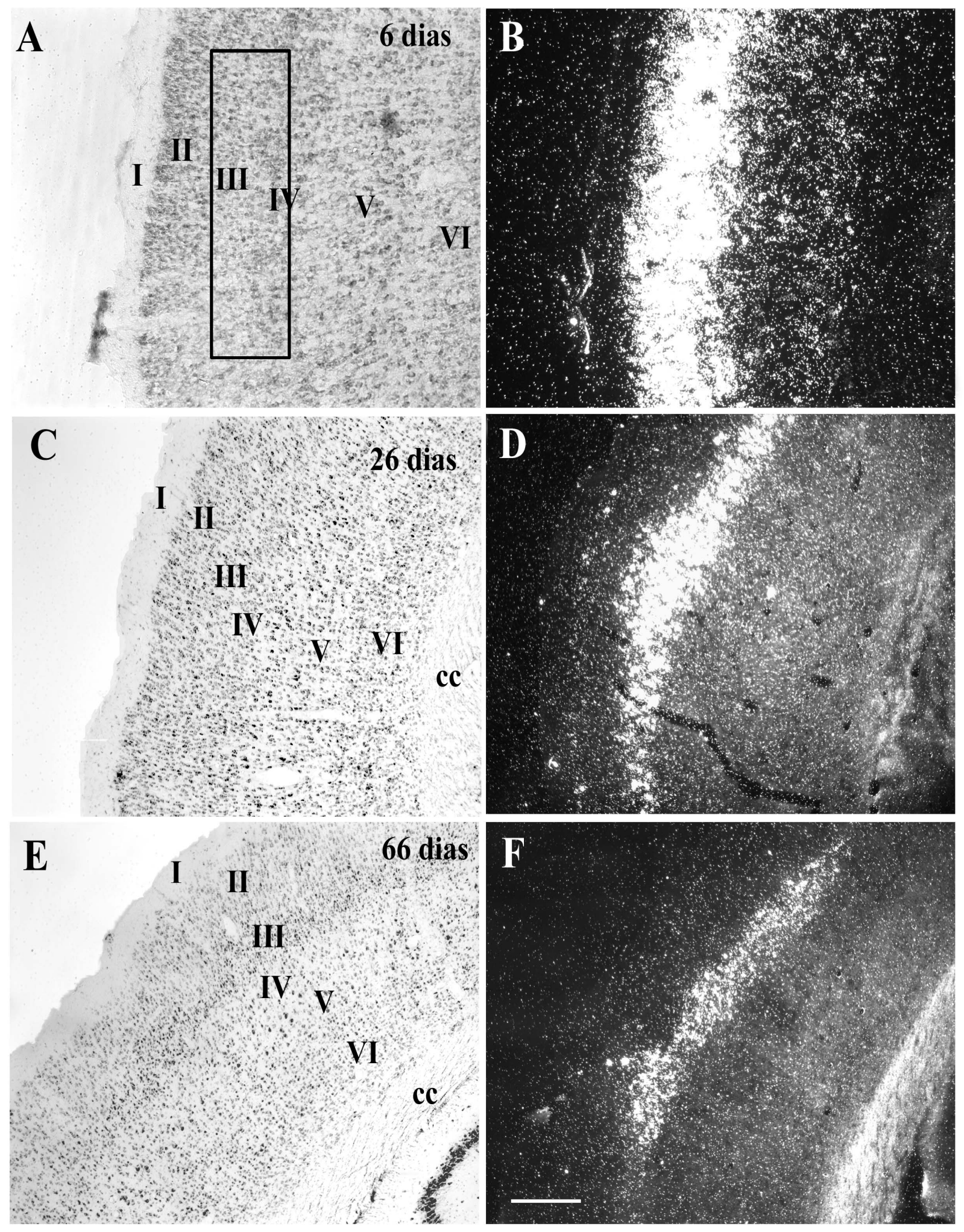

Figura 1. Transcrito regulado pela cocaína e anfetamina (CART) no córtex cerebral em diferentes fases do desenvolvimento ( 6,26 e 66 dias). A, C e E: Fotomicrografia de campo claro demonstrando a citoarquitetura das camadas corticais (I-VI). B, D e F: Fotomicrografia de campo claro demonstrando a hibridização com ribossonda do CART marcada com ${ }^{35} \mathrm{~S}$. Retângulo delimita a área de contagem da DOI. Barra $200 \mu \mathrm{m}$. 


\section{Córtex Somatossensorial}

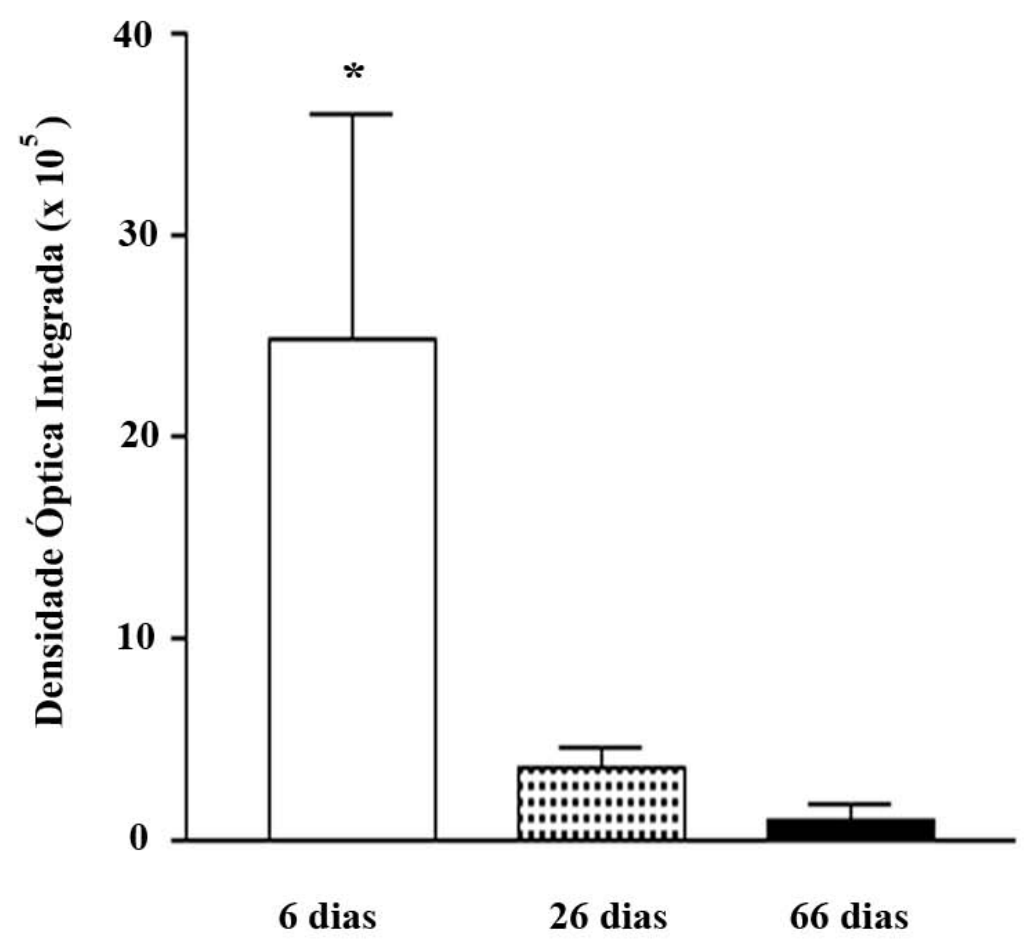

Figura 2. Análise estatística da expressão do transcrito regulado pela cocaína e anfetamina (CART) no córtex somatossensorial em diferentes fases do desenvolvimento pós-natal (6, 26 e 66 dias). A quantificação foi feita utilizando a densidade óptica integrada (DOI). *p<0,05 (ANOVA). 


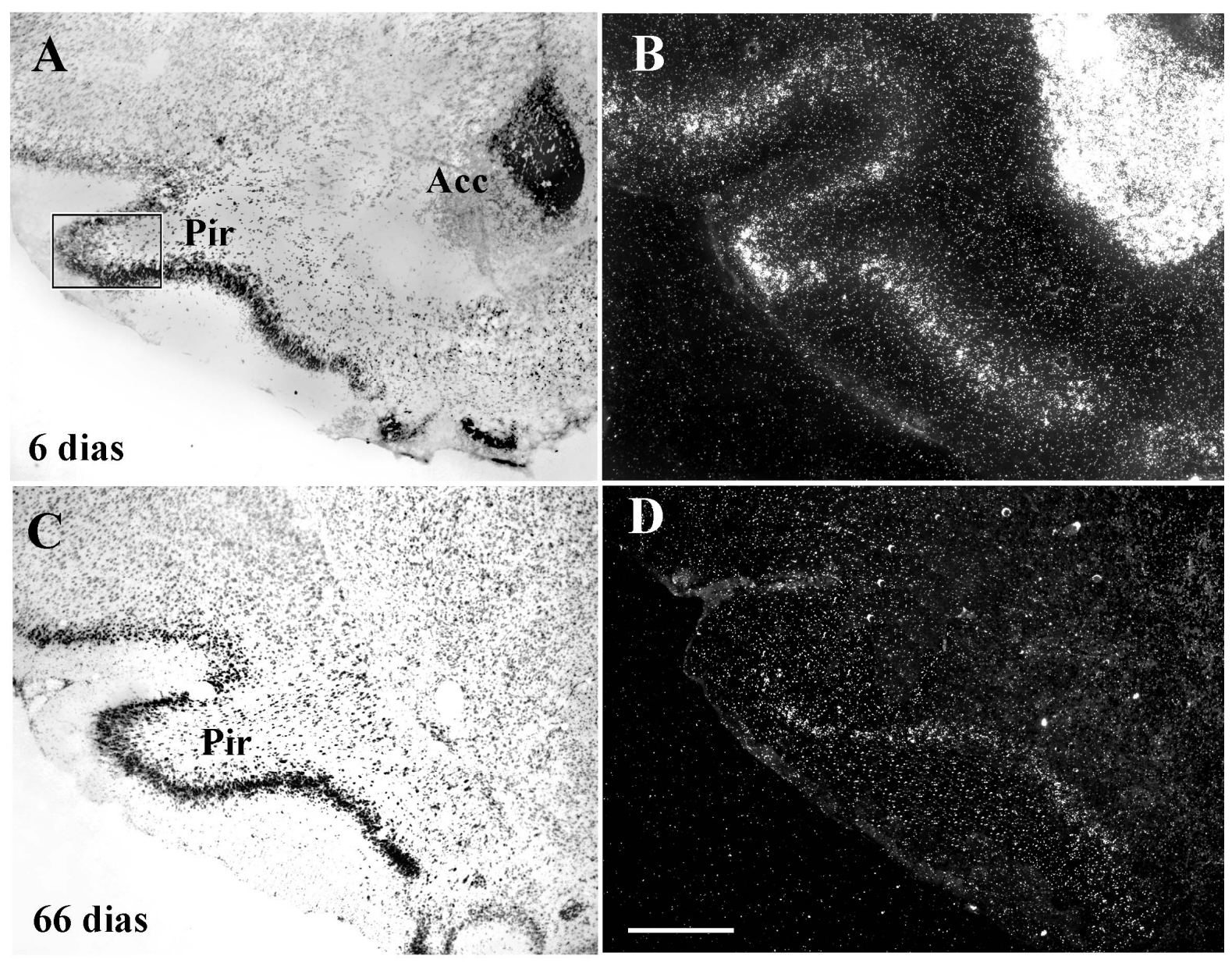

Figura 3. Transcrito regulado pela cocaína e anfetamina (CART) no córtex piriforme em diferentes fases do desenvolvimento $(6,26$ e 66 dias). A e C: Fotomicrografias de campo claro demonstrando a citoarquitetura da região. B e D: Fotomicrografias de campo escuro demonstrando a hibridização com ribossonda do CART marcada com ${ }^{35} \mathrm{~S}$. Abreviações: Acc, accumbens; Pir, córtex piriforme. Retângulo delimita a área de contagem da densidade óptica integrada. Barra $400 \mu \mathrm{m}$. 


\section{Córtex Piriforme (rostral)}

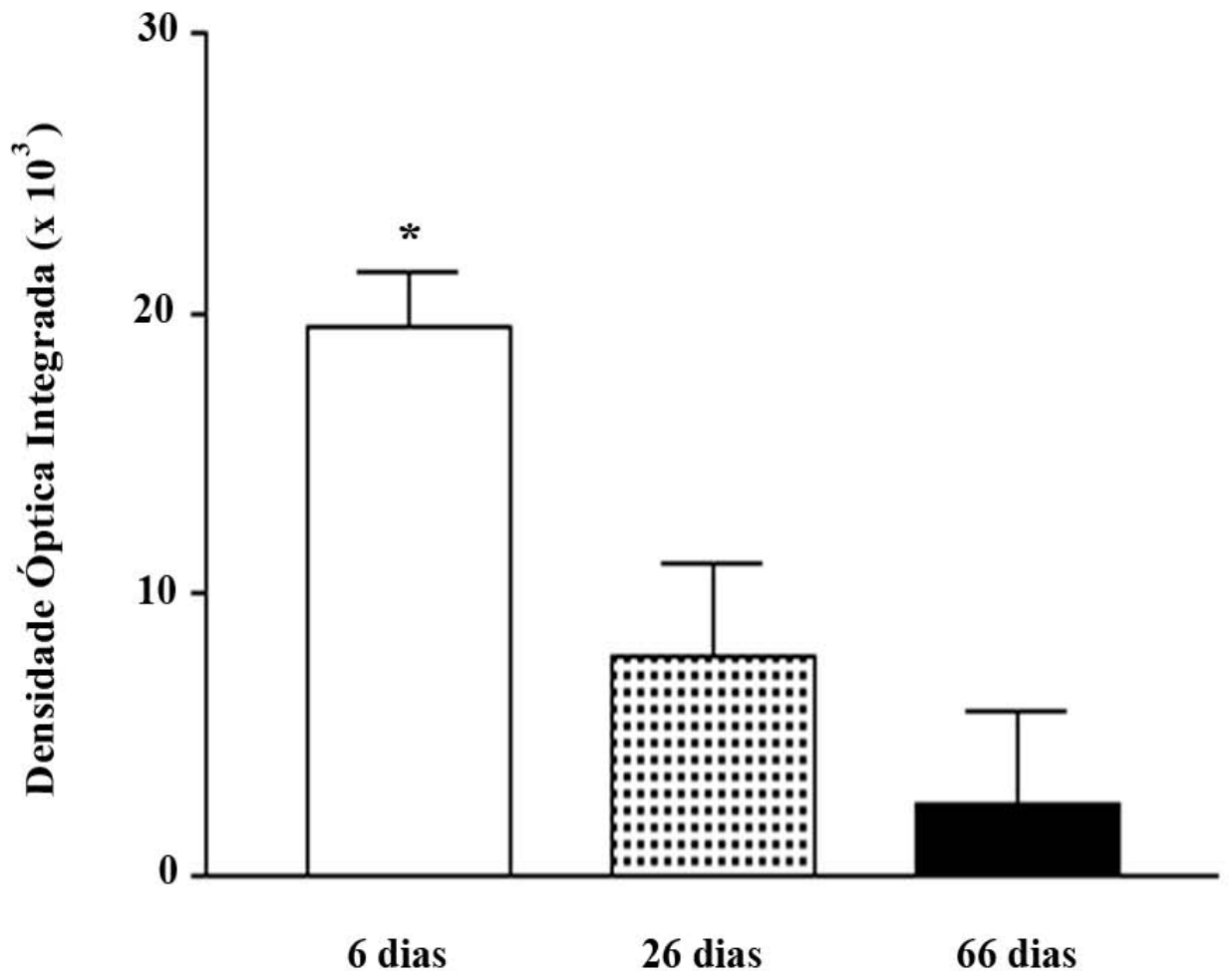

Figura 4. Análise estatística da expressão do transcrito regulado pela cocaína e anfetamina (CART) no córtex piriforme em diferentes fases do desenvolvimento pós-natal (6, 26 e 66 dias). A quantificação foi feita utilizando a densidade óptica integrada (DOI). $*$ p $<0,05$ (ANOVA). 


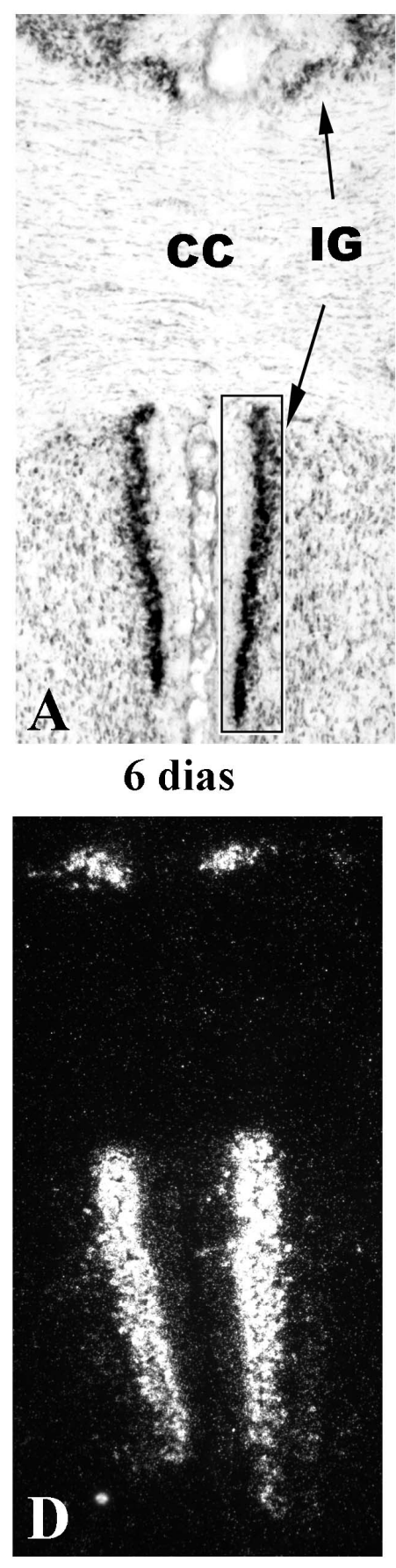

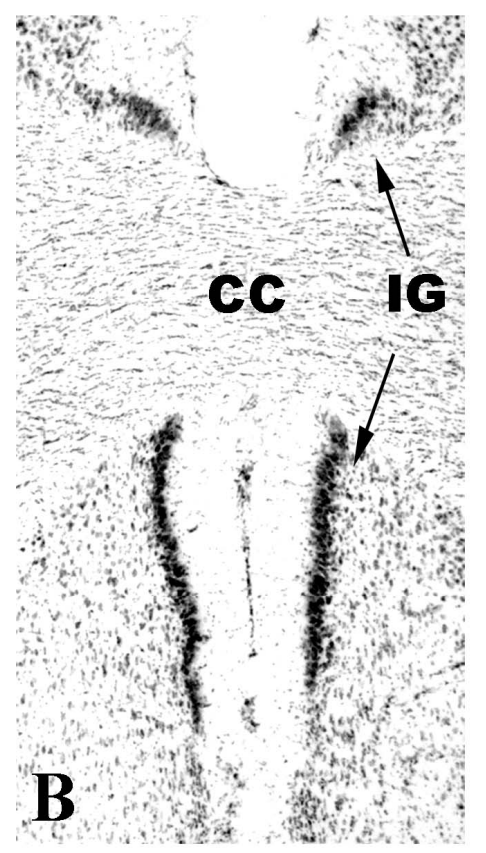

26 dias

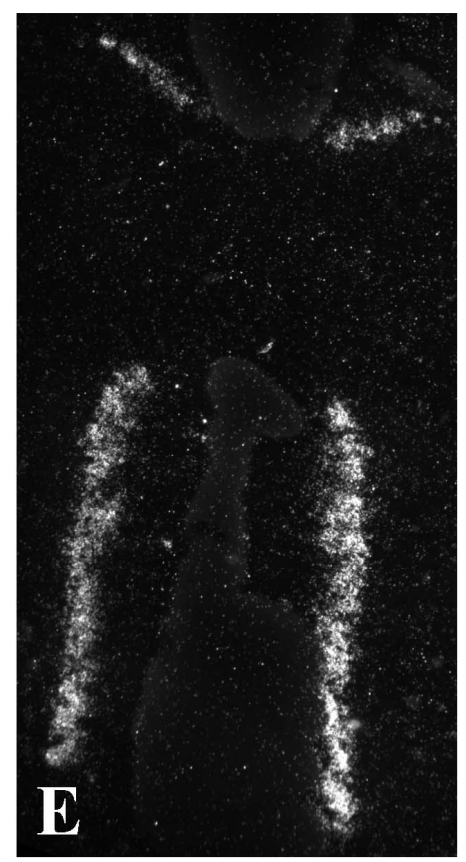

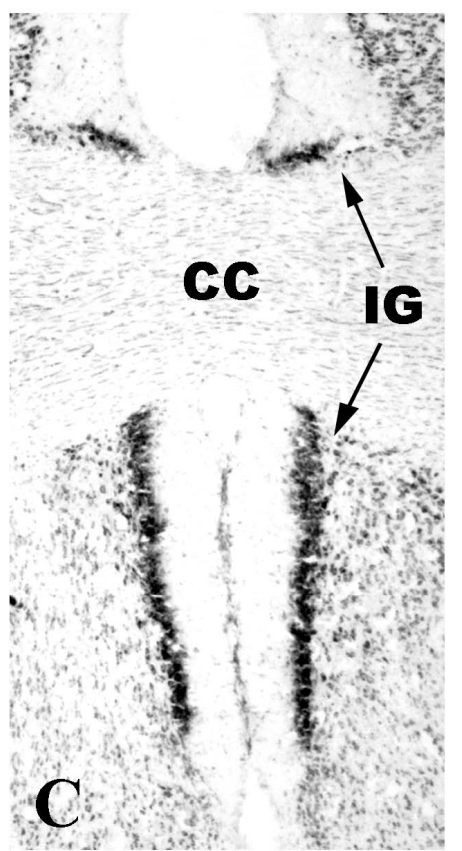

66 dias

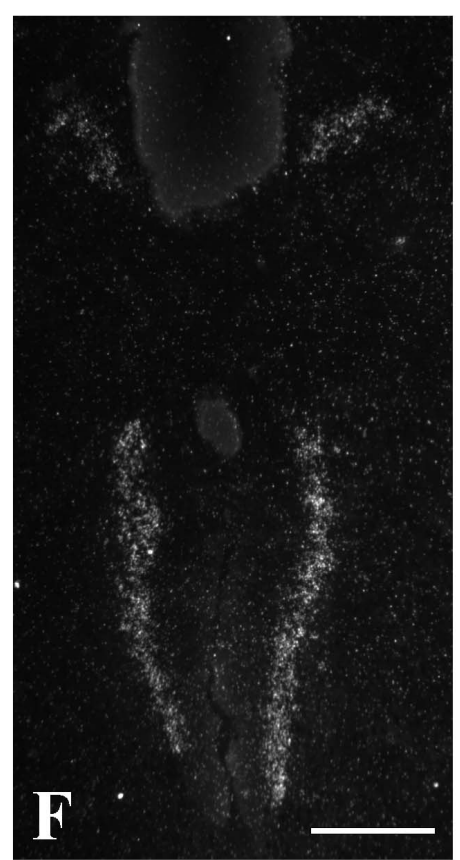

Figura 5. Transcrito regulado pela cocaína e anfetamina (CART) no indusium griseum (IG) em diferentes fases do desenvolvimento $(6,26$ e 66 dias). A, B e C: Fotomicrografias de campo claro demonstrando a citoarquitetura da região. D, E e F: Fotomicrografias de campo escuro demonstrando a hibridização com ribossonda do CART marcada com ${ }^{35} \mathrm{~S}$. Abreviação: cc, corpo caloso. Retângulo delimita a área de contagem da densidade óptica integrada. Barra $200 \mu \mathrm{m}$. 


\section{Indusium Griseum}

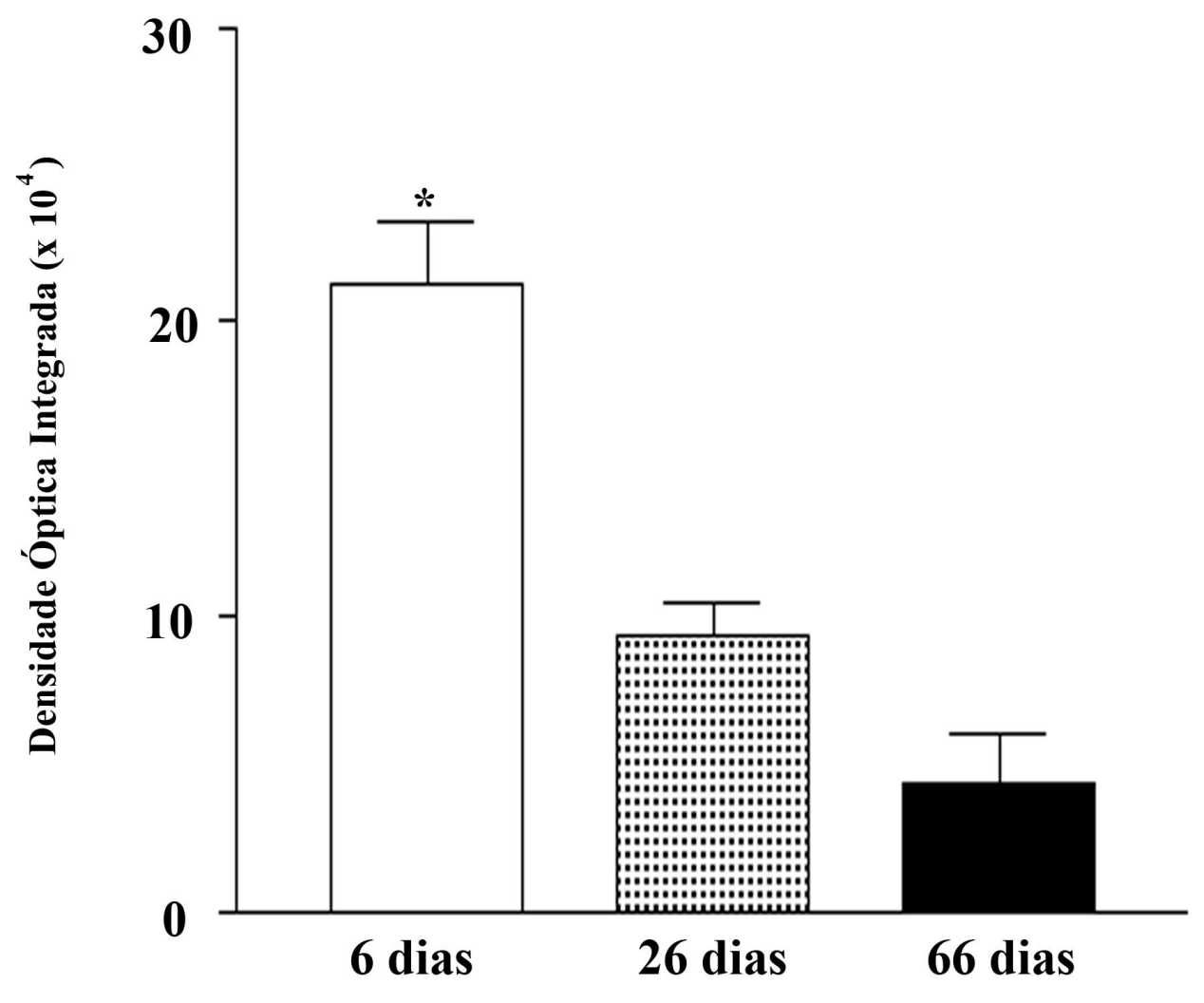

Figura 6. Análise estatística da expressão do transcrito regulado pela cocaína e anfetamina (CART) no indusium griseum em diferentes fases do desenvolvimento pós-natal (6, 26 e 66 dias). A quantificação foi feita utilizando a densidade óptica integrada (DOI). $*$ p $<0,05$ (ANOVA). 


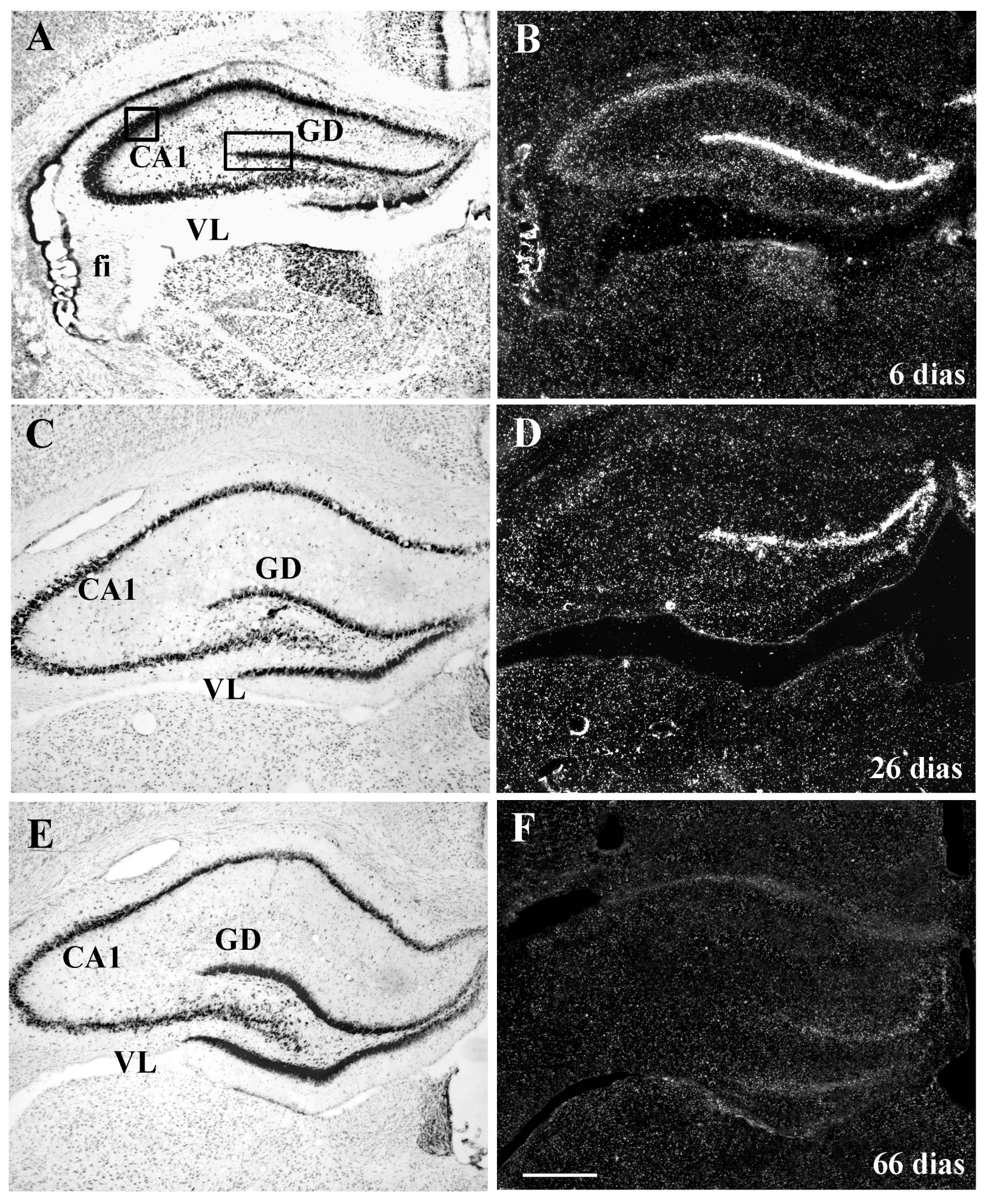

Figura 7. Transcrito regulado pela cocaína e anfetamina (CART) em regiões do hipocampo em diferentes fases do desenvolvimento (6, 26 e 66 dias). A, C e E: Fotomicrografias de campo claro demonstrando a citoarquitetura da região. B, D e F: Fotomicrografias de campo escuro demonstrando a hibridização com ribossonda do CART marcada com ${ }^{35}$ S. Abreviações: CA1, campo CA1; GD, diro denteado; fi, fimbrias do hipocampo e VL, ventrículo lateral. Retângulos delimitam as áreas das contagens das densidades ópticas integradas. Barra $200 \mu \mathrm{m}$. 


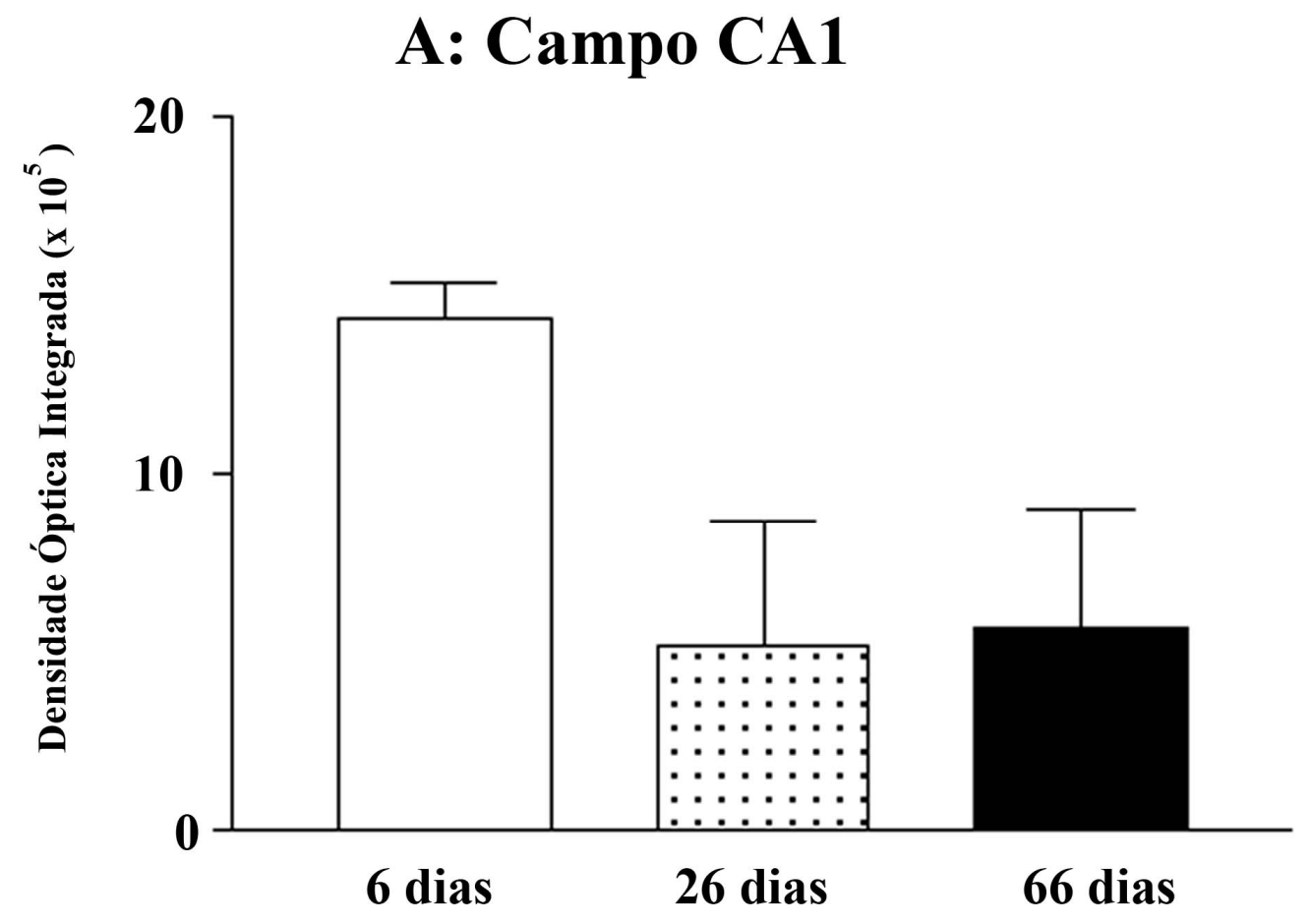

B: Giro Denteado

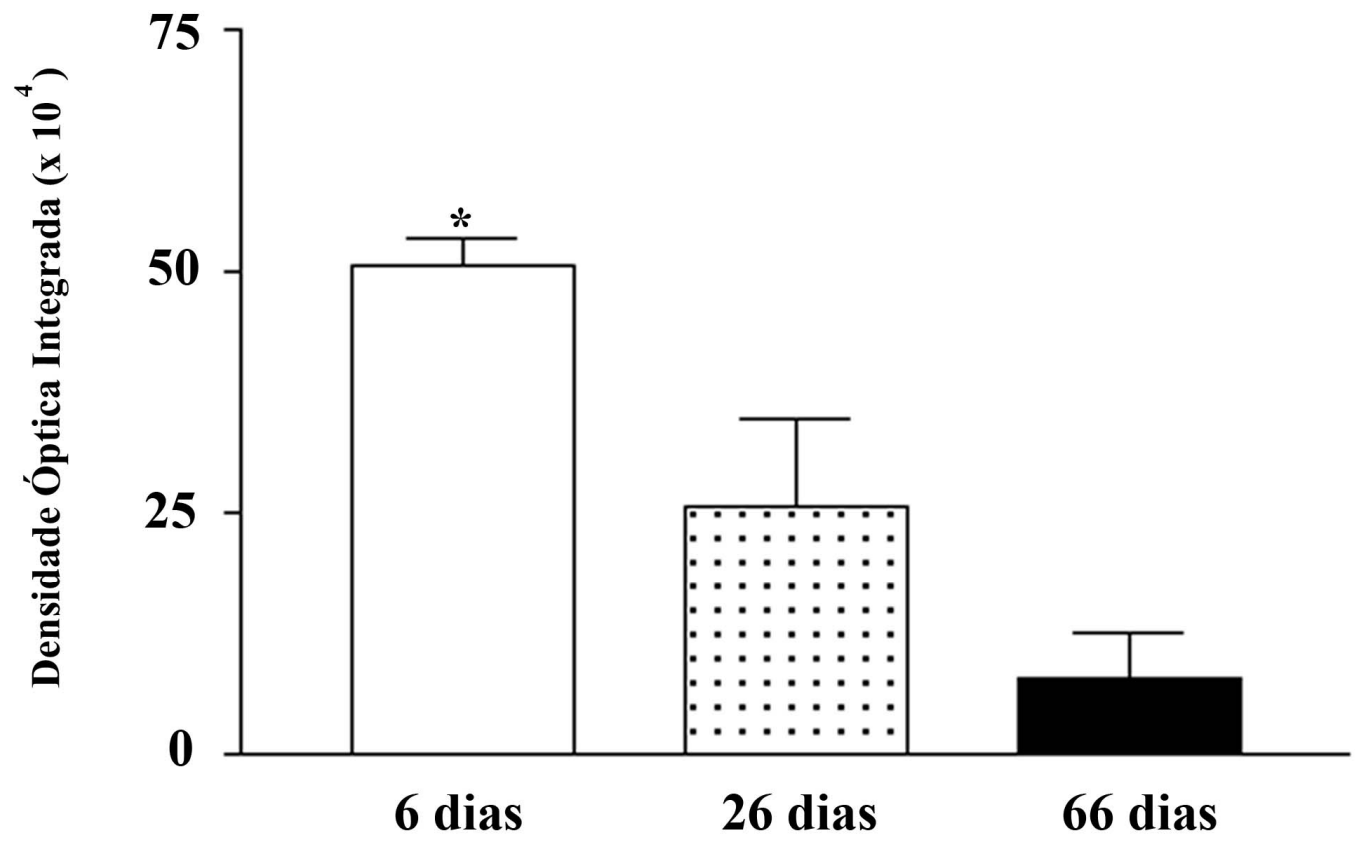

Figura 8. Análise estatística da expressão do transcrito regulado pela cocaína e anfetamina (CART) em regiões do hipocampo em diferentes fases do desenvolvimento pós-natal (6, 26 e 66 dias). A quantificação foi feita utilizando a densidade óptica integrada (DOI). A: no campo CA1. B: no giro denteado. ${ }^{*} \mathrm{p}<0,05$ (ANOVA). 


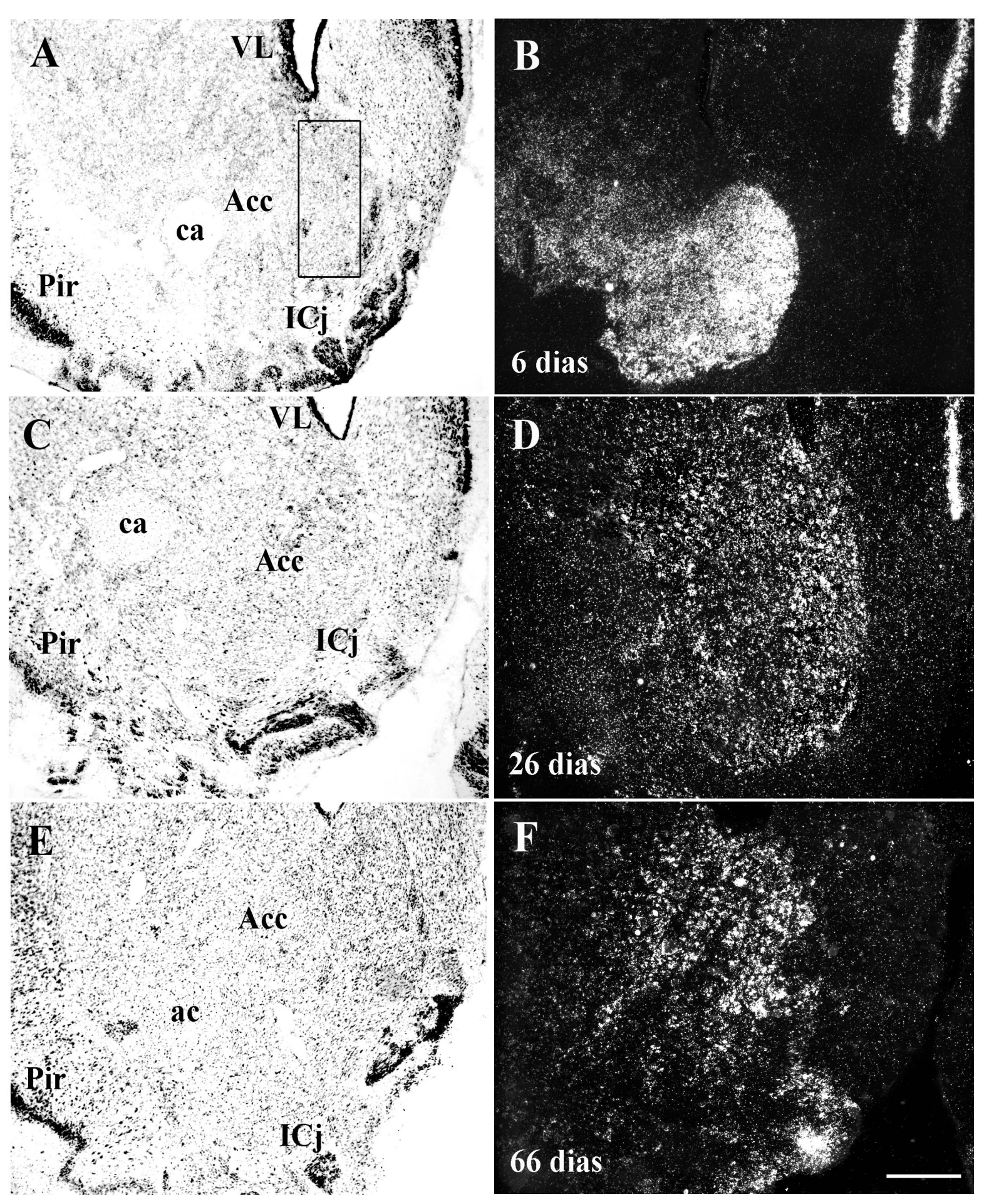

Figura 9. Transcrito regulado pela cocaína e anfetamina (CART) no accumbens em diferentes fases do desenvolvimento $(6,26$ e 66 dias). A, C e E: Fotomicrografias de campo claro demonstrando a citoarquitetura da região. B, D e F: Fotomicrografias de campo escuro demonstrando a hibridização com ribossonda do CART marcada com ${ }^{35} \mathrm{~S}$. Abreviações: ca, comissura anterior; VL, ventrículo lateral. Retângulo delimita a área da contagem da densidade óptica integrada. Barra $200 \mu \mathrm{m}$. 


\section{Accumbens}

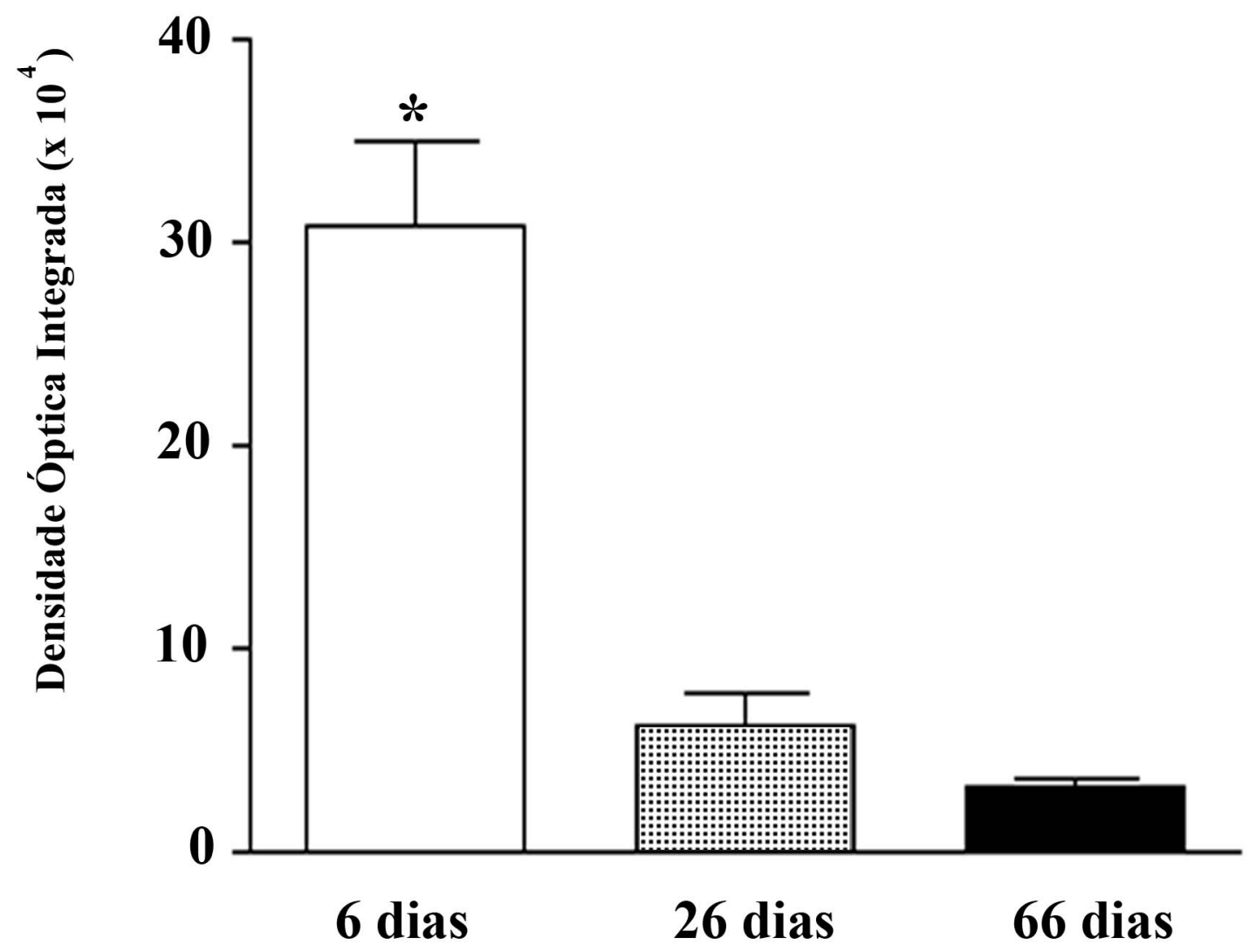

Figura 10. Análise estatística da expressão do transcrito regulado pela cocaína e anfetamina (CART) no accumbens em diferentes fases do desenvolvimento pós-natal (6, 26 e 66 dias). A quantificação foi feita utilizando a densidade óptica integrada (DOI). * p $<0,05$ (ANOVA). 

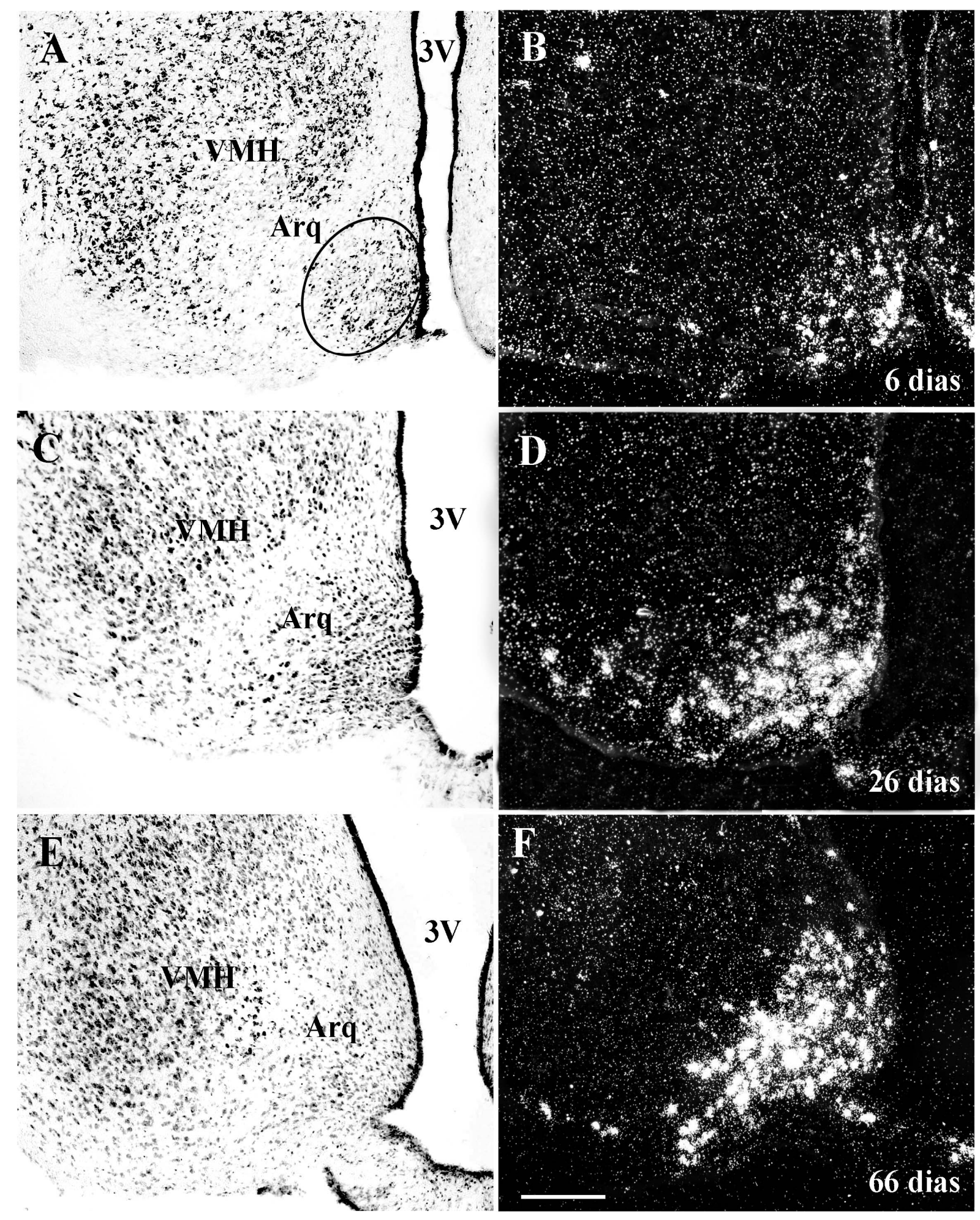

Figura 11. Transcrito regulado pela cocaína e anfetamina (CART) no núcleo arqueado em diferentes fases do desenvolvimento (6, 26 e 66 dias). A, C e E: Fotomicrografias de campo claro demonstrando a citoarquitetura da região. B, D e F: Fotomicrografias de campo escuro demonstrando a hibridização com ribossonda do CART marcada com ${ }^{35} \mathrm{~S}$. Abreviações: $3 \mathrm{~V}$, terceiro ventrículo; Arq, núcleo arqueado; VMH, núcleo ventro-medial do hipotálamo. Elipse delimita a área da contagem da densidade óptica integrada. Barra $100 \mu \mathrm{m}$. 


\section{Núcleo Arqueado}

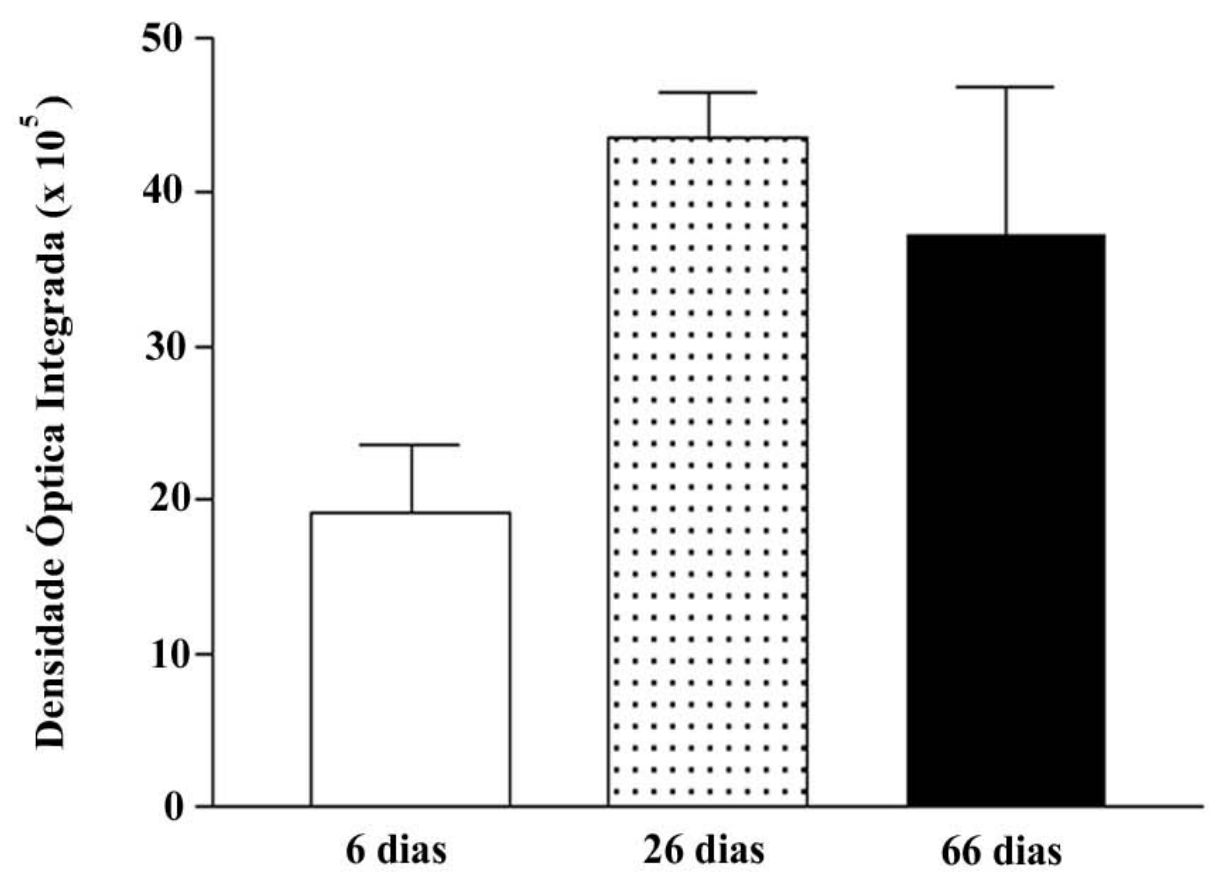

Figura 12. Análise estatística da expressão do transcrito regulado pela cocaína e anfetamina (CART) no núcleo arqueado em diferentes fases do desenvolvimento pós-natal (6, 26 e 66 dias). A quantificação foi feita utilizando a densidade óptica integrada (DOI). 

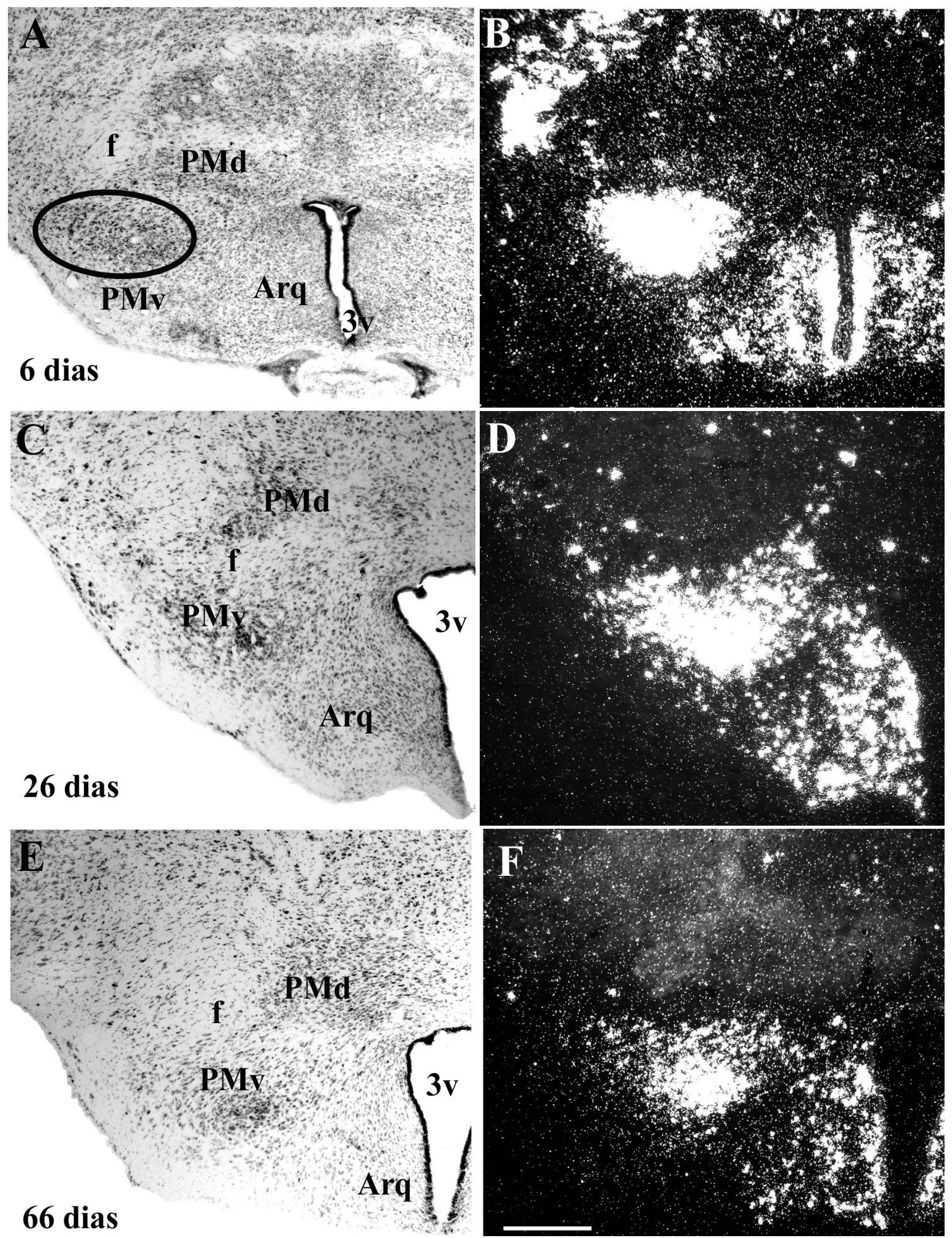

Figura 13. Transcrito regulado pela cocaína e anfetamina (CART) no núcleo pré-mamilar ventral (PMv) em diferentes fases do desenvolvimento (6, 26 e 66 dias). A, C e E: Fotomicrografias de campo claro demonstrando a citoarquitetura da região. B, D e F: Fotomicrografias de campo escuro demonstrando a hibridização com ribossonda do CART marcada com ${ }^{35} \mathrm{~S}$. Abreviações: $3 \mathrm{~V}$, terceiro ventrículo; Arq, núcleo arqueado; f, fórnice; PMd, núcleo pré-mamilar dorsal. Elipse delimita a área da contagem da densidade óptica integrada. Barra $200 \mu \mathrm{m}$. 


\section{Núcleo Pré-Mamilar Ventral}

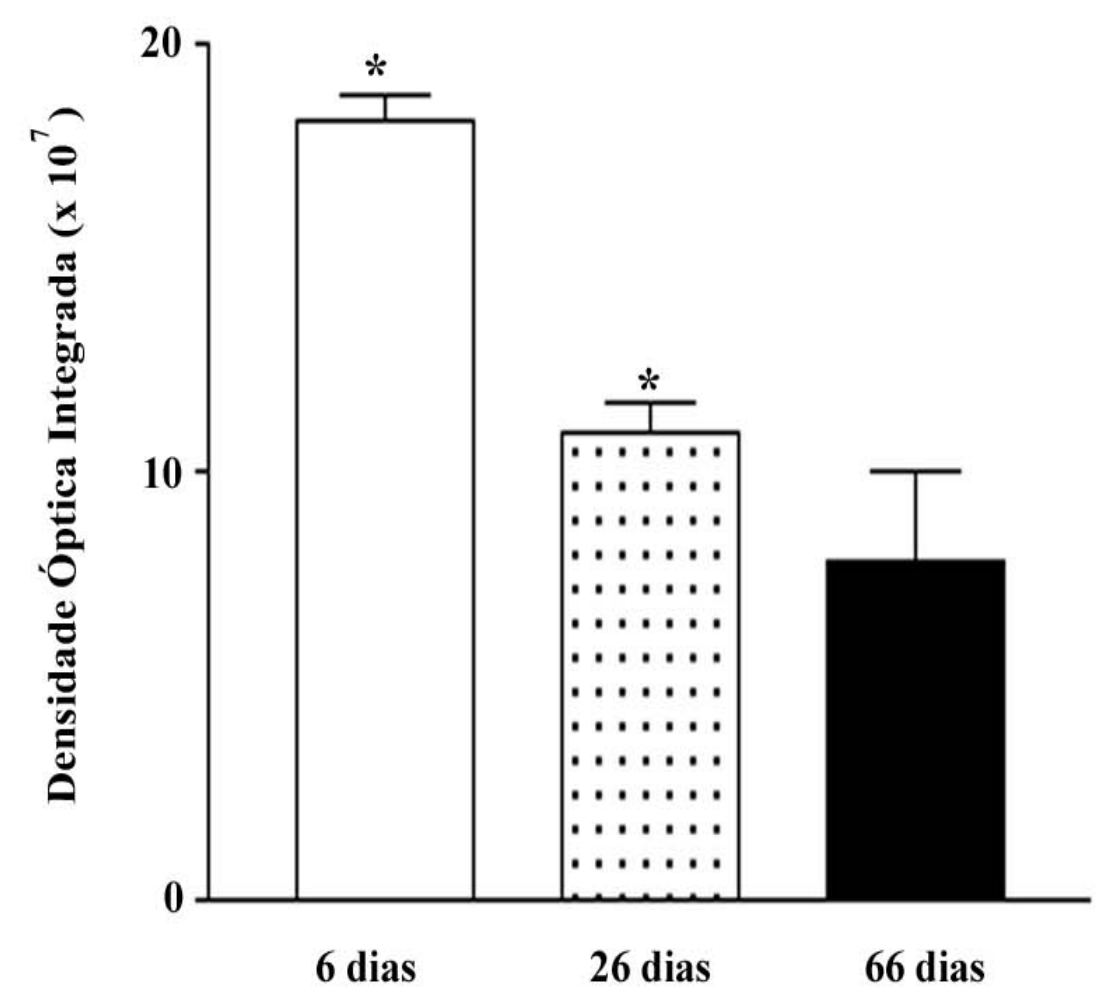

Figura 14. Análise estatística da expressão do transcrito regulado pela cocaína e anfetamina (CART) no núcleo pré-mamilar ventral em diferentes fases do desenvolvimento pós-natal $(6,26$ e 66 dias). A quantificação foi feita utilizando a densidade óptica integrada (DOI). ${ }^{*} \mathrm{p}<0,05$ (ANOVA). 

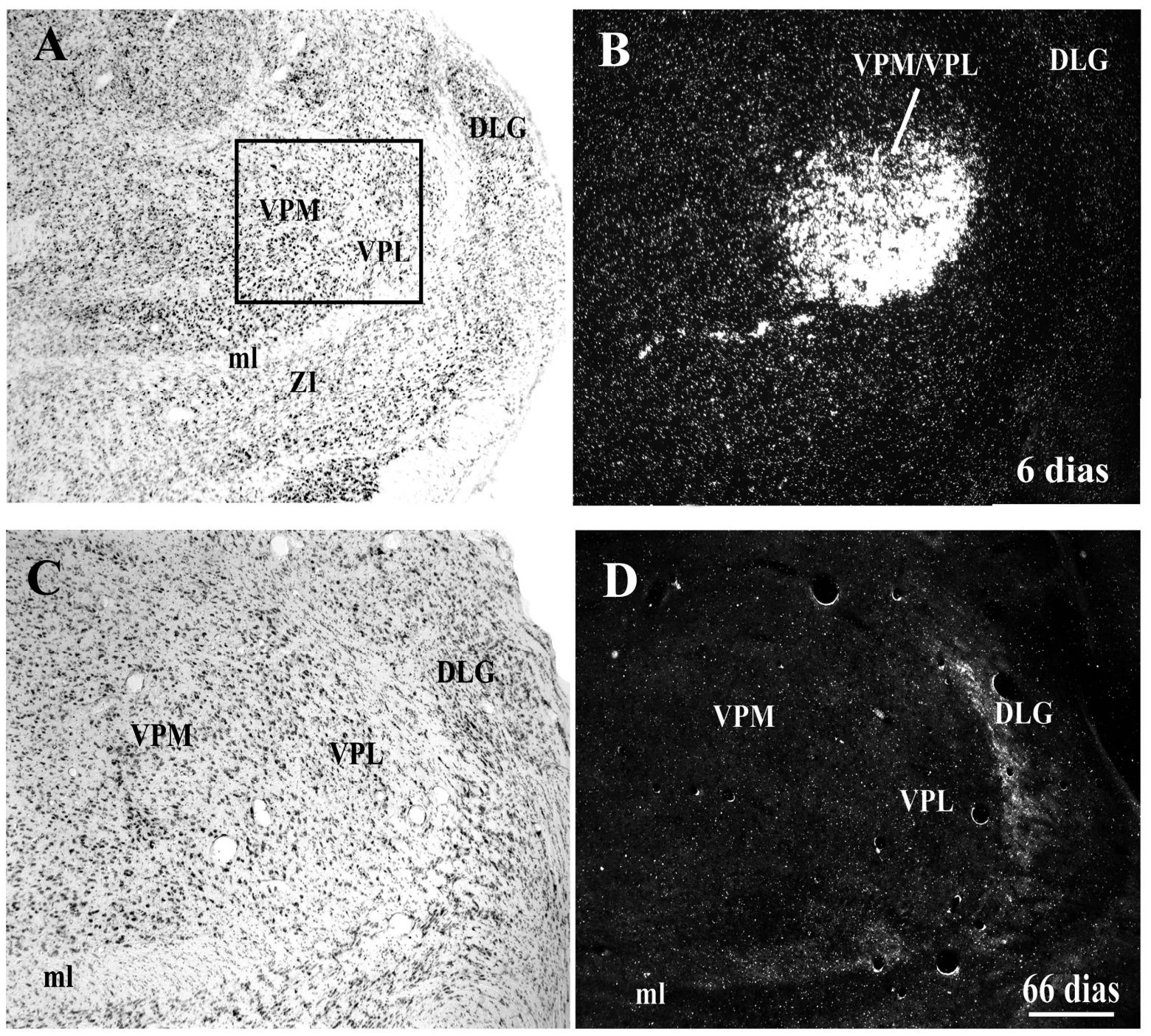

Figura 15. Transcrito regulado pela cocaína e anfetamina (CART) nos núcleos ventro-póstero medial e ventropóstero lateral do tálamo em diferentes fases do desenvolvimento (6, 26 e 66 dias). A e C: Fotomicrografias de campo claro demonstrando a citoarquitetura da região. B e D: Fotomicrografias de campo escuro demonstrando a hibridização com ribossonda do CART marcada com ${ }^{35} \mathrm{~S}$. Abreviações: DLG, núcleo geniculado lateral dorsal; ml, lemnisco medial; VPL, núcleo ventropóstero lateral do tálamo; VPM, núcleo ventro-póstero medial do tálamo; ZI, zona incerta. Retângulo delimita a área da contagem da densidade óptica integrada. Barra $200 \mu \mathrm{m}$. 


\section{Núcleos ventro-póstero lateral e ventro-póstero medial do tálamo}

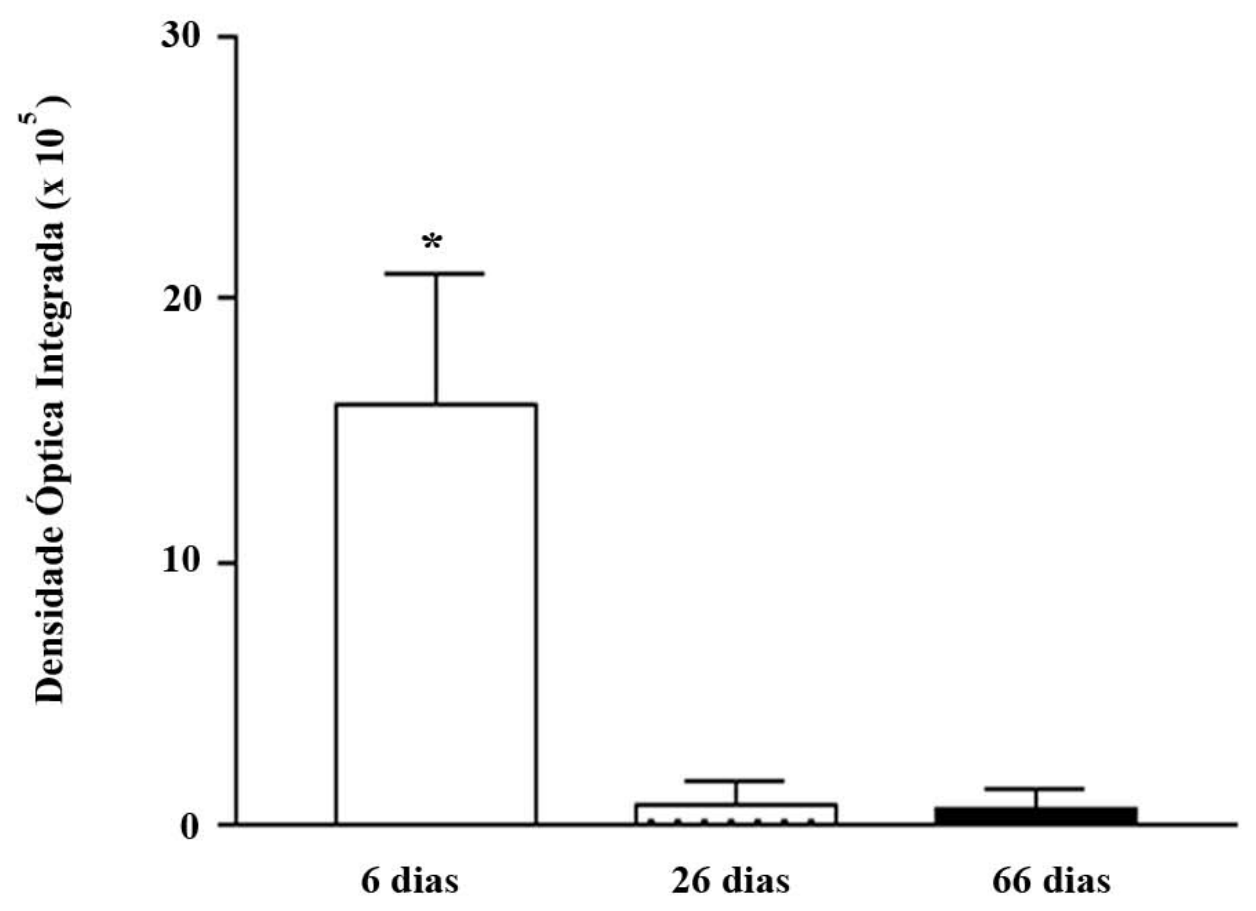

Figura 16. Análise estatística da expressão do transcrito regulado pela cocaína e anfetamina (CART) nos núcleos ventro-póstero medial e ventro-póstero lateral do tálamo em diferentes fases do desenvolvimento pósnatal $(6,26$ e 66 dias). A quantificação foi feita utilizando a densidade óptica integrada (DOI). $* \mathrm{p}<0,05$ (ANOVA). 

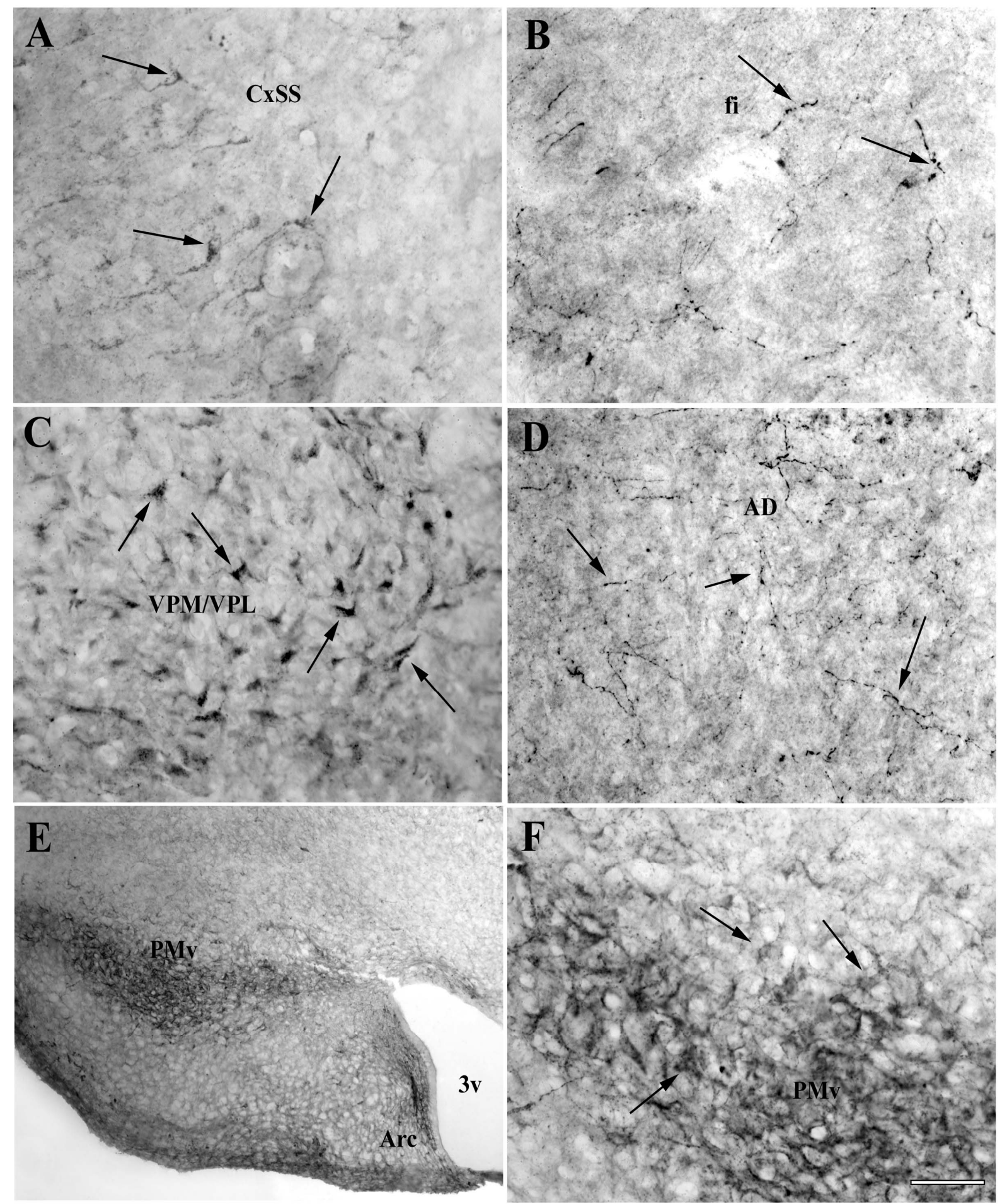

Figura 17. Distribuição do peptídeo CART em regiões encefálicas no animal de 6 dias. Fotomicrografias de campo claro mostrando imunorreatividade ao CART (CART-ir, setas) em células do córtex somatossensorial (A, CXSS), em fibras na fímbria do hipocampo (B, fi), em células no núcleo ventro-póstero medial/lateral do tálamo (C, VPM/VPL), em fibras no núcleo ântero-dorsal do tálamo (D, AD), em células do núcleo pré-mamilar ventral (E e F, PMv). Abreviações: 3v, terceiro ventrículo; Arc, núcleo arqueado. Barra $50 \mu \mathrm{m}$ (A,B,C e F) e $200 \mu \mathrm{m}$ (E). 


\section{DISCUSSÃO}

\subsection{Discussão da metodologia}

Há aspectos sobre a hibridização in situ, principal ferramenta utilizada nesse trabalho, que devem ser levados em consideração. A técnica da hibridização in situ, que consiste na ligação de uma sonda de fita simples de RNA complementar marcada (no caso com radioisótopo de enxofre) com o RNAm alvo, deve ser feita com muita cautela, pois o material utilizado deve estar livre da enzima ribonuclease (RNase). Caso tal enzima esteja presente no tecido estudado, haverá variação da quantidade do RNA alvo no tecido por perda de RNAm. Assim, devemos considerar a possibilidade de ocorrer perda de RNA durante o processamento do tecido, e conseqüentemente variação na expressão entre as idades estudadas. Para evitar esta possibilidade, o procedimento de hibridização foi realizado de uma só vez, para cada região estudada. É importante ressaltar, no entanto, que apesar dos animais de 6 dias apresentarem uma maior expressão de CART, algumas regiões apresentaram variação qualitativa. Os núcleos ventro-póstero lateral (VPL) e ventro-póstero medial (VPM) do tálamo, por exemplo, em animais de 6 dias apresentaram expressão bastante alta o que não foi observado na mesma região dos animais dos demais grupos nos quais não houve expressão, em acordo com trabalhos publicados anteriormente (Koylu et. al., 1998). Além disso, observamos que esta variação não foi observada em outras regiões, como o CA3 do hipocampo e o núcleo arqueado. Portanto, nossos resultados sugerem que a variação da expressão do CART é uma característica do desenvolvimento e não um artefato da técnica utilizada.

A técnica de imunohistoquímica realizada para o tecido dos animais de 6 dias foi modificada em relação a forma que utilizamos para os tecidos de animais adultos. Em animais adultos, todo o procedimento é feito com o tecido antes que ele seja montado nas lâminas ("free-floating"). No entanto, para os animais de 6 dias, que apresentam ainda pouca mielinazação, os cortes histológicos são muito frágeis e precisam ser montados em lâminas antes do procedimento de imunohistoquímica. Com isso, embora nossos resultados demonstrem uma boa equivalência entre expressão de RNAm e peptídeo, a eficiência da marcação pode ter sido diminuída pelo fato dos anticorpos e das soluções atingirem apenas uma das faces do tecido. 


\subsection{Discussão dos Resultados}

Louis (1996) demonstrou que o CART tem papel na regulação da re-captação da dopamina e no desenvolvimento de neurônios dopaminérgicos. A dopamina, juntamente com o GABA, faz parte do sistema de controle do comportamento motivacional. Ambos estão em condições alteradas no accumbens em situações que envolvem abuso de drogas e em modelos de reforço e recompensa (Koob, 1992; Kelley, 2004). Assim como a dopamina e o GABA, o CART também está presente no accumbens, e também tem sido estudado por fazer parte do sistema de recompensa e reforço. Injeções do peptídeo CART diretamente no accumbens não causam efeito algum na locomoção, mas quando combinadas com cocaína ou anfetamina sistêmica o que se observa é uma redução no aumento da atividade locomotora causada por tais drogas (Kuhar e Vechia, 1999; Jaworski et al., 2003, Kim et al., 2003). Injeções do peptídeo CART na área tegmental ventral provoca pequeno aumento na atividade motora. Tal aumento é controlado negativamente de forma dose-dependente por haloperidol (antagonista do receptor de dopamina) (Kim et al., 2003; Missale et al., 1998). Curiosamente, injeções do peptídeo CART no accumbens bloqueiam também de forma dose-dependente a atividade locomotora produzida pela injeção de dopamina nesse mesmo núcleo (Jaworski et al., 2003). Em contrapartida, animais com deleção ("knock-out") do gene CART respondem menos a administração de cocaína, ao mesmo tempo em que o comportamento de adicção é observado com menos intensidade nesses animais (Hubert \& Kuhar, 2006). Em humanos, estudos realizados com vítimas de overdose causada por cocaína, demonstraram que os níveis de CART estão mais baixos na área tegmental ventral e mais altos no accumbens. (Tang et al., 2003; Albertson et al., 2004). Além disso, foi demonstrado que injeções icv do peptídeo CART, provoca aumento nos níveis do ácido 3,4-dihidroxifenilacético (DOPAC) indicando que houve aumento da liberação de dopamina. No trabalho de Brunetti e colaboradores (2000), mencionado anteriormente, experimentos in vitro demonstraram que o peptídeo CART tem a capacidade de inibir a liberação de dopamina na fenda sináptica. Estudos da expressão de CART durante o desenvolvimento revelaram que existem regiões que expressam CART somente em fases específicas do desenvolvimento embrionário, e que este neuropeptídeo deve regular de alguma forma o desenvolvimento ontogenético de neurônios dopaminérgicos do mesencéfalo. Os mesmos autores sugerem que o CART é o primeiro peptídeo expresso dentre os que apresentam função neurotransmissora/neuromoduladora no cérebro adulto (Brischoux et al., 2001, 2002). Dessa maneira, considerando as funções já conhecidas da dopamina na mediação de atividades locomotoras e de comportamentos 
relacionados com recompensa e reforço, podemos sugerir que o CART pode estar participando do desenvolvimento e manutenção dessas vias. Nossos resultados apontaram para um aumento da expressão de CART no núcleo accumbens de animais em desenvolvimento. O significado deste aumento ainda precisa ser pesquisado. No entanto, uma vez que a relação do CART com o sistema dopaminérgico é bem descrita, sugerimos que ele possa atuar no estabelecimento e na plasticidade das conexões dopaminérgicas.

Estudos demonstraram que a proteína CART promove diferenciação celular e prolonga a viabilidade de neurônios hipocampais (Louis, 1996). O hipocampo é a região com maior quantidade do chamado fator neurotrófico derivado do encéfalo (BDNF - brain-derived neurotrophic factor) (Ivanova e Beyer, 2001). O BDNF regula o crescimento axonal e dendrítico e a plasticidade sináptica de neurônios hipocampais e corticais, além de estar relacionado com diversos outros aspectos do desenvolvimento nervoso, de plasticidade neuronal, de neuroproteção e patologias neurodegenerativas (Murphy et al., 1998; McAllister et al., 1995; McAllister et al., 1997; Kang et al., 1995; Sherwood e Lo, 1999; Figurov et al., 1996; Patterson et al., 1996; Thoenen, 1995; Tucker et al., 2001; McFarlane, 2000). Estudos têm demonstrado que a expressão do RNAm BDNF é controlada por diversos peptídeos como o peptídeo vasoativo intestinal (VIP), o polipeptídeo hipofisário ativador da adenilato ciclase (PACAP), o hormônio liberador de corticotropinas (CRF) e mais recentemente o CART (Pellegri et al., 1998; Bayatti et al., 2005). Especificamente em relação ao CART, autores observaram que ele promove aumento tanto da expressão do RNAm quanto da proteína BDNF em cultura de células hipocampais (Wu et al., 2006). Ábrahán e colaboradores (2007), em estudos sobre o desenvolvimento pós-natal de ratos, descreveram que a expressão do peptídeo CART e da calbindina (CB) (responsável pela regulação de potenciação de longa duração - long term potenciation - LTPs - no hipocampo) está relacionada com a maturação pós-natal das células granulares do giro denteado do hipocampo. Além disso, grandes quantidades de peptídeo CART são observadas nessas células no momento em que o hipocampo atinge sua maturidade funcional. Nossos resultados estão de acordo com as evidências encontradas, já que os animais em desenvolvimento apresentam maior expressão de CART do que os animais adultos. Diante disso, sugerimos que o CART participa do desenvolvimento e plasticidade de neurônios do giro denteado do hipocampo.

$\mathrm{O}$ indusium griseum é motivo de controvérsia quanto a sua divisão anatômica. Alguns autores o consideram parte da formação hipocampal e outros não (Golgi, 1886; Obersteiner, 1890; Fish, 1893; Smith, 1897 apud Wyss e Sripanidkulchai, 1983). Porém, estudos demonstraram que as células das camadas do indusium griseum são anatomicamente análogas 
às células das diferentes porções do hipocampo, sendo as céluas mais superficiais do indusium griseum similares à células do giro denteado (Wyss e Sripanidkulchai, 1983). Diante de tal similaridade, e de nossos resultados que demonstraram maior expressão de CART no indusium griseum dos animais de 6 dias, sugerimos que o CART atua no indusium griseum como no hipocampo, no sentido de induzir o desenvolvimento e/ou facilitar a plasticidade de seus neurônios..

Como mencionado anteriormente, pesquisadores demonstraram que o BDNF promove crescimento dendrítico no córtex cerebral (McAllister et al., 1997). Além disso, estudos recentes têm demonstrado o envolvimento do BDNF na maturação celular de neurônios na camada IV do córtex cerebral (Itami et al., 2007). A camada IV do córtex recebe a maioria das projeções dos núcleos talâmicos, entre eles os núcleos ventro-póstero lateral e ventropóstero medial (Killackey, 1983; Jensen e Killakey 1987a, Jones, 1985). As projeções que originam nos núcleos póstero-ventrais do tálamo são oriundas conduzem informações somatossensoriais de todo o corpo incluindo as vibrissas em vários mamíferos como roedores. Pesquisadores têm demonstrado que as conexões entre o tálamo e o córtex cerebral dependem de sinalizações específicas durante seu desenvolvimento (Allendoerfer e Shatz, 1994; Molnár e Blakemore, 1995). Estudos com camundongos com deleção do receptor de neurotrofina (da família do BDNF) p75 demonstraram que há participação das moléculas dessa família no desenvolvimento das vias tálamo-corticais (Ma et al., 2002; McQuillen et al., 2002). Embora estudos fisiológicos sejam necessários, nossos dados sugerem que o CART pode atuar em conjunto com o BDNF, exercendo funções neurotróficas nas vias tálamo-corticais já que tanto a camada IV do córtex quanto os núcleos póstero-ventrais do tálamo apresentam expressão de CART aumentada nos animais em desenvolvimento.

Além do córtex somatossensorial, observamos um aumento da expressão do CART no córtex piriforme. $\mathrm{O}$ córtex piriforme, também chamado de córtex olfatório primário, recebe informações mono-sinápticas do bulbo olfatório e, no roedor, é considerado como a maior dentre as subdivisões do córtex cerebral. Como em outras áreas corticais, nele são encontrados poucos neurônios GABAérgicos e muitos neurônios glutamatérgicos (Suzuki e Bekkers, 2006; Suzuki e Bekkers 2007). Estudos demonstraram que as respostas fisiológicas desses neurônios não estão completas até pelo menos a segunda semana de vida (Schwob et al., 1984; Schwob e Price, 1984a,b). Nossos resultados demonstraram maior expressão de CART no córtex piriforme dos animais em desenvolvimento. Diante disto, podemos propor 
que o CART pode estar modulando informações sensoriais ou ainda atuando no desenvolvimento das vias olfativas em questão.

Na região do hipotálamo, observamos uma grande expressão de CART no núcleo prémamilar ventral de animais de 6 dias de idade. O núcleo pré-mamilar ventral é conhecido por estar envolvido com os comportamentos agressivo e sexual. Estudos de nosso laboratório demonstram que neurônios CART do núcleo pré-mamilar de ratos machos são ativados diante da exposição a feromônios de fêmeas da mesma espécie (Cavalcante et al., 2006). É importante mencionar que a comunicação feromonal é vital para os ratos recém-nascidos poderem se aproximar da mãe e achar o mamilo no momento do seu aleitamento (Shair et al., 1997; Polan e Hofer, 1999). Além do CART, outra molécula encontrada no PMv é a óxido nítrico sintase (NOs), indicadora da presença do óxido nítrico (NO) (Yokosuka et al., 1997) Estudos têm sugerido participação do NO no desenvolvimento cerebral e papel importante no controle de funções dos comportamentos reprodutivo e agressivo (Gally et al., 1990, Mani et al., 1994; Moretto et al., 1993; Nelson et al., 1995). Como vimos anteriormente, pesquisadores demonstraram que os neurônios CART são estimulados pelo NO (Koylu et al., 2000; Ahima et al., 1999; Isse et al., 1999). Portanto, mesmo conscientes da necessidade de maiores investigações, nossos dados sugerem que o CART pode participar do processamento feromonal durante o aleitamento ou no desenvolvimento de vias relacionadas com comportamento agressivo e sexual.

Como mencionado anteriormente, os neurônios do núcleo arqueado que expressam CART também expressam POMC e OBRb (receptor para leptina), o que indica participação no controle do comportamento alimentar (Elmquist et al., 1998). A variação da expressão do POMC em resposta à quantidade de leptina circulante é bem descrita (Ahima et al., 1999). Ausência ou diminuição das concentrações de leptina causa uma diminuição da expressão de POMC enquanto que o aumento ou a administração de leptina induz um aumento da expressão de POMC. Como já mencionado, estudos também demonstraram que camundongos com deficiência de leptina (ob/ob) apresentam diminuição da expressão de CART (Kristensen et al., 1998). Administração de leptina induz aumento de CART no núcleo arqueado destes animais. É interessante observar que, durante o desenvolvimento os níveis circulantes de leptina são bastante altos. Neste período, a variação dos níveis de leptina não corresponde à estados de saciedade ou fome, como observado em adultos (Ahima et al., 1998). Nossos resultados não mostraram diferença estatística entre as idades estudadas na expressão do CART no núcleo arqueado. Contudo, experimentos adicionais seriam necessários para um maoir aprofundamento da análise dos resultados obtidos uma vez que os níveis de leptina, que 
flutuam de acordo com as reservas energéticas do organismo, e portanto de acordo com o comportamento alimentar, exercem influência sobre a expressão do CART (Zhang et al., 1994; Cowley et al., 2001; Elias et al., 2000; Kristensen et al., 1998). Dessa forma, o controle da alimentação dos animais adultos seria necessário para que nós pudéssemos explorar melhor o significado desses resultados. 


\section{CONCLUSÕES}

Concluímos que em vários núcleos prosencefálicos o CART encontra-se aumentado em animais de 6 dias, comparado com animais de 26 e 66 dias.

Especificamente, observamos que o CART encontra-se aumentado nos animais de 6 dias em regiões relacionadas a:

a) processamento sensorial, incluindo o cótex cerebral somatossensorial, o córtex piriforme e os núcleos ventro-póstero lateral e medial do tálamo;

b) formação e/ou processamento de memória, como o giro denteado e o indusium griseum;

c) reforço e recompensa, como o núcleo accumbens;

d) discriminação feromonal, como o núcleo pré-mamilar ventral. 


\section{REFERÊNCIAS BIBLIOGRÁFICAS}

Abrahám H, Orsi G, Seress L. Ontogeny of cocaine- and amphetamine-regulated transcript (CART) peptide and calbindin immunoreactivity in granule cells of the dentate gyrus in the rat. Int J Dev Neurosci. 2007; 25(5):265-74.

Adams LD, Gong W, Vechia SD, Hunter RG, Kuhar MJ. CART: from gene to function. Brain Res. 1999 Nov 27; 848(1-2):137-40.

Ahima RS, Kelly J, Elmquist JK, Flier JS. Distinct physiologic and neuronal responses to decreased leptin and mild hyperleptinemia. Endocrinology. 1999; 140(11):4923-31.

Ahima RS, Prabakaran D, Flier JS. Postnatal leptin surge and regulation of circadian rhythm of leptin by feeding. Implications for energy homeostasis and neuroendocrine function. J Clin Invest. 1998; 101(5):1020-7.

Albertson DN, Pruetz B, Schmidt CJ, Kuhn DM, Kapatos G, Bannon MJ. Gene expression profile of the nucleus accumbens of human cocaine abusers: evidence for dysregulation of myelin. J Neurochem. 2004 Mar; 88(5):1211-9.

Allendoerfer KL, Shatz CJ. The subplate, a transient neocortical structure: its role in the development of connections between thalamus and cortex. Annu Rev Neurosci. 1994; 17:185218.

Bayatti N, Hermann H, Lutz B, Behl C. Corticotropin-releasing hormone-mediated induction of intracellular signaling pathways and brain-derived neurotrophic factor expression is inhibited by the activation of the endocannabinoid system. Endocrinology. 2005 Mar;146(3):1205-13. Epub 2004 Dec 9.

Bertagna X. Proopiomelanocortin-derived peptides. Endocrinol Metab Clin North Am 1994; 23:467-485.

Bouret SG, Simerly RB. Minireview: Leptin and development of hypothalamic feeding circuits. Endocrinology. 2004; 145(6):2621-6.

Brischoux F, Fellmann D, Risold PY. Ontogenetic development of the diencephalic MCH neurons: a hypothalamic 'MCH area' hypothesis. Eur J Neurosci. 2001;13(9):1733-44. 
Brischoux F, Griffond B, Fellmann D, Risold PY. Early and transient ontogenetic expression of the cocaine- and amphetamine-regulated transcript peptide in the rat mesencephalon: correlation with tyrosine hydroxylase expression. J Neurobiol. 2002; 52(3):221-9.

Brunetti L, Orlando G, Michelotto B, Recinella L, Vacca M. Cocaine- and amphetamineregulated transcript peptide-(55-102) and thyrotrophin releasing hormone inhibit hypothalamic dopamine release. Eur J Pharmacol. 2000; 409:103-107.

Castro MG, Morrison E. Post-translational processing of Proopiomelanocortin in the pituitary and in the brain. Crit Rev Neurobiol. 1997; 11(1):35-57. Review.

Cavalcante JC, Bittencourt JC, Elias CF. Female odors stimulate CART neurons in the ventral premammillary nucleus of male rats. Physiol Behav. 2006; 88 (1-2):160-6.

Chavkin C, James IF, Goldstein A. Dynorphin is a specific endogenous ligand of the kappa opioid receptor. Science. 1982; 215:413-5.

Chen L, Gu Y, Huang LY. The mechanism of action for the block of NMDA receptor channels by the opioid peptide dynorphin. J Neurosci. 1995; 15:4602-11.

Chen L, Gu Y, Huang LY. The opioid peptide dynorphin directly blocks NMDA receptor channels in the rat. J Physiol. 1995; 428(Pt3):575-81.

Chen L, Huang LY. Dynorphin block of N-methyl-D-aspartate channels increases with the peptide length. J Pharmacol Exp Ther. 1998; 284:826-31.

Couceyro PR, Koylu EO, Kuhar MJ. Further studies on the anatomical distribution of CART by in situ hybridization. J Chem Neuroanat. 1997; 12(4):229-241.

Cowley MA, Smart JL, Rubinstein M, Cerdán MG, Diano S, Horvath TL, Cone RD, Low MJ. Leptin activates anorexigenic POMC neurons through a neural network in the arcuate nucleus. Nature. 2001; 24;411(6836):480-4.

Devaskar SU, Ollesch C, Rajakumar RA, Rajakumar PA. Developmental changes in ob gene expression and circulating leptin peptide concentrations. Biochem Biophys Res Commun. 1997; 238(1):44-7. 
Douglass J, McKinzie A, Couceyro P. PCR Differential Display Identifies a Rat Brain mRNA That is Transcriptionally Regulated by Cocaine and Amphetamine. J of Neurosci. 1995; 15(3):2471-2481.

Elias CF, Kelly JF, Lee CE, Ahima RS, Drucker DJ, Saper CB, Elmquist JK. Chemical Characterization of Leptin-Activated Neurons in the Rat Brain. J Comp Neurol. 2000; 423:261-281.

Elias CF, Lee C, Kelly J, Aschkenasi C, Ahima RS, Couceyro PR, Kuhar MJ, Saper CB, Elmquist JK. Leptin Activates Hypothalamic CART Neurons Projecting to the Spinal Cord. Neuron. 1998; 21:1375-1385.

Elias CF, Lee CE, Kelly JF, Ahima RS, Kuhar M, Saper CB, Elmquist JK. Characterization of CART neurons in the rat and human hypothalamus. J Comp Neurol. 2001; 26;432(1):1-19.

Elliott PJ, Nemeroff CB. The Neurobiology of Neurotensin - Neural Endocr Peptides Recept. Plenum Pub Corp; 1986.

Elmquist JK, Bjobaek C, Ahima RS, Flier JS, Saper CB. Distribution of leptin receptor mRNA isoforms in rat brain. J Comp Neurol. 1998; 395:535-547.

Fan W, Boston BA, Kesterson RA, Hruby VJ, Cone RD. Role of melanocortinergic neurons in feeding and the agouti obesity syndrome. Lett Nat. 1997; 385:165-168.

Fekete C, Mihaly E, Luo LG, Kelly J, Clausen JT, Mão Q, et al. Association of cocaine- and amphetamine- regulated transcript- immunoreactive elements with thyrotrophin-releasing hormone- synthesizing neurons in the hypothalamic paraventricular nucleus and its role in the regulation of the hypothalamic - pituitary- thyroid axis during fasting. J Neurosci. 2000; 20:9224-34.

Fekete C, Wittmann G, Liposits Z, Lechan RM. Origin of cocaine- and amphetamineregulated transcript (CART)-immunoreactive innervation of the hypothalamic paraventricular nucleus. J Comp Neurol. 2004; 469:340-50.

Figurov A, Pozzo-Miller LD, Olafsson P, Wang T, Lu B. Regulation of synaptic responses to high-frequency stimulation and LTP by neurotrophins in the hippocampus. Nature. 1996; 381:706-709.

Fish PA. The indusium of the callosum. J Comp Neurol. 1893; 3:61-68. 
Freeman ME, Kanyicska B, Lerant A, Nagy G. Prolactin: structure, function, and regulation of secretion. Physiol Rev. 2000; 80:1523-631.

Frohman LA, Maeda K, Berelowitz M, Szabo M, Thominet J. Effects of neurotensin on hypothalamic and pituitary hormone secretion. Ann N Y Acad Sci. 1982; 400: 172-182.

Gally JA, Montague PR, Reeke GN Jr, Edelman GM. The NO hypothesis: possible effects of a short-lived, rapidly diffusible signal in the development and function of the nervous system. Proc Natl Acad Sci U S A. 1990 May; 87(9):3547-51.

Golgi C. Sulla Fina Anatomia Degli Organi Centrali Del Sistema Nervoso. Milano: U. Hoepli; 1886

Gonzalez MI, Vaziri S, Wilson CA. Behavioral effects of alpha-MSH and MCH after central administration in the female rat. Peptides. 1996; 17(1):171-7.

Hara Y, Shiosaka S, Senba E, Sakanaka M, Inagaki S, Takagi H, Kawai Y, Takatsuki K, Matsusaki T \& Tohyama M. Ontogeny of the neurotensin-containing neuron system of the rat: immunohistochemical analysis. I. Forebrain and diencephalon. J Comp Neurol. 1982; 208:177-195.

Ivanova T, Beyer C. Pre- and postnatal expression of brain-derived neurotrophic factor mRNA/protein and tyrosine protein kinase receptor B mRNA in the mouse hippocampus. Neurosci Lett. 2001 Jul 6; 307(1):21-4.

Hubert GW, Kuhar MJ. Colocalization of CART peptide with prodynorphin and dopamine D1 receptors in the rat nucleus Accumbens. Neuropeptides. 2006; 40:409-415.

Isse T, Ueta Y, Serino R, Noguchi J, Yamamoto Y, Nomura M, Shibuya I, Lightman SL, Yamashita $\mathrm{H}$. Effects of leptin on fasting-induced inhibition of neuronal nitric oxide synthase mRNA in the paraventricular and supraoptic nuclei of rats. Brain Res. 1999; 846(2):229-35.

Itami C, Kimura F, Nakamura S. Brain-derived neurotrophic factor regulates the maturation of layer 4 fast-spiking cells after the second postnatal week in the developing barrel cortex. J Neurosci. 2007; 27(9):2241-52.

Jaworski JN, Vicentic A, Hunter RG, Kimmel HL, Kuhar MJ. CART peptides are modulators of mesolimbic dopamine and psychostimulants. Life Sci. 2003; 73(6):741-7. 
Jennes L, Stumpf WE, Kalivas PW. Neurotensin: Topographical distribution in rat brain by immunohistochemistry. J Comp Neurol. 1982; 210:211-224.

Jensen KF, Killackey HP. Terminal arbors of axons projecting to the somatosensory cortex of the adult rat. I. The normal morphology of specific thalamocortical afferents. J Neurosci. 1987 Nov; 7(11):3529-43.

Jones EG. The Thalamus. New York: Plenum; 1985.

Kandel ER, Schwartz JH, Jessell TM. Principles of Neural Science. New York: McGraw-Hill; 2000 .

Kang H, Schuman EM. Long-lasting neurotrophin-induced enhancement of synaptic transmission in the adult hippocampus. Science. 1995; 267:1658-1662.

Kawano H, Tsuruo Y, Bando H, Daikoku S. Hypophysiotrophic TRH-producing neurons identified by combining immunohistochemetry for pro-TRH and retrograde tracing. J Comp Neurol. 1991; 307:531-8.

Killackey HP, Gould HJ 3rd, Cusick CG, Pons TP, Kaas JH. The relation of corpus callosum connections to architectonic fields and body surface maps in sensorimotor cortex of new and old world monkeys. J Comp Neurol. 1983 Oct 1; 219(4):384-419.

Kelley AE. Memory and addiction: shared neural circuitry and molecular mechanisms. Neuron. 2004; 44(1):161-79.

Kim JH, Creekmore E, Vezina P. Microinjection of CART peptide 55-102 into the nucleus accumbens blocks amphetamine-induced locomotion. Neuropeptides. 2003 Dec; 37(6):36973.

Kristensen P, Judge ME, Thim L, Ribel U, Christjansen KN, Wulff BS, Clausen JT, Jensen PB, Madsen OD, Vrang N, Larsen PJ, Hastrup S. Hypothalamic CART is a new anorectic peptide regulated by leptin. Nature. 1998; 393(6680):72-6.

Koob GF. Drugs of abuse: anatomy, pharmacology and function of reward pathways. Trends Pharmacol Sci. 1992; 13(5):177-84.

Koylu EO, Couceyro PR, Lambert PD, Ling NC, DeSouza EB and Kuhar MJ. Immunohistochemical Localization of Novel CART Peptides in Rat Hypothalamus, Pituitary and Adrenal Gland. J Neuroendocrinol. 1997; 9:823-833. 
Koylu EO, Couceyro PR, Lambert PD, Kuhar MJ. Cocaine- and Amphetamine- Regulated Transcript Peptide Immunohistochemical Localization in the Rat Brain. J Comp Neurol. 1998; 391:115-132.

Koylu EO, Weruaga E, Balkan B, Alonso JR, Kuhar MJ, Pogun S. Co-localization of cart peptide immunoreactivity and nitric oxide synthase activity in rat hypothalamus. Brain Res. 2000; 868(2):352-7.

Kuhar MJ, Dall Vechia SE. CART peptides: novel addiction- and feeding-related neuropeptides. Trends Neurosci. 1999; 22(7):316-20.

Lechan RM. Update on thyrotrophin-releasing hormone. Thyroid Today. 1993; 16:1-12.

Lechan RM, Segerson TP. Pro-TRH gene expression and precursor peptides in rat brain. Observations by hybridization analysis and immunocytochemistry. Ann NY Acad Sci. 1989; 553:29-59.

Louis JCM, inventor. Methods of Preventing Neuron Degeneration and Promoting Neuron Regeneration, US patent WO96/34619. 1996 Apr 24.

Ludwig DS, Tritos NA, Mastaitis JW, Kulkarni R, Kokkotou E, Elmquist J, Lowell B, Flier JS, Maratos-Flier E. Melanin-concentrating hormone overexpression in transgenic mice leads to obesity and insulin resistance. J. Clin Invest. 2001; 107(3):379-86.

Ma L, Harada T, Harada C, Romero M, Hebert JM, McConnell SK, Parada LF. Neurotrophin3 is required for appropriate establishment of thalamocortical connections. Neuron. 2002 Nov 14;36(4):623-34.

Mani SK, Allen JM, Rettori V, McCann SM, O'Malley BW, Clark JH. Nitric oxide mediates sexual behavior in female rats. Proc Natl Acad Sci USA. 1994 Jul 5;91(14):6468-72.

McAllister AK, Katz LC, Lo DC. Opposing roles for endogenous BDNF and NT-3 in regulating cortical dendritic growth. Neuron. 1997; 18:767-778.

McAllister AK, Lo DC Katz LC. Neurotrophins regulate dendritic growth in developing visual cortex. Neuron. 1995; 15:791-803. 
McCann SM, Vijayan E, Koening J, Krulich L. The effects of neurotensin on anterior pituitary hormone secretion. Ann NY Acad Sci. 1982; 400:160-171.

McFarlane S. Dendritic morphogenesis: building an arbor. Mol Neurobiol. 2000; 22:1-9.

McQuillen PS, DeFreitas MF, Zada G, Shatz CJ. A novel role for p75NTR in subplate growth cone complexity and visual thalamocortical innervation. J Neurosci. 2002 May 1;22(9):358093.

Merchenthaler I, Liposits Z. Mapping of thyrotrophin-releasing hormone (TRH) neuronal systems of rat forebrain projecting to the median eminence and the OVLT Immunocytochemistry combined with retrograde labeling at the light and electron microscope levels. Acta Biol Hung. 1994; 45:361-74.

Miller CL, Hruby VJ, Matsunaga TO, Bickford PC. Alpha-MSH and MCH are functional antagonists in a CNS auditory gating paradigm. Peptides. 1993; 14(3):431-40.

Missale C, Nash SR, Robinson SW, Jaber M, Caron MG. Dopamine receptors: from structure to function. Physiol Rev. 1998 Jan; 78(1):189-225.

Monzon ME, de Souza MM, Izquierdo LA, Izquierdo I, Barros DM, de Barioglio SR. Melanin-concentrating hormone $(\mathrm{MCH})$ modifies memory retention in rats. Peptides. 1999; 20(12):1517-9.

Moretto M, López FJ, Negro-Vilar A. Nitric oxide regulates luteinizing hormone-releasing hormone secretion. Endocrinology. 1993 Nov; 133(5):2399-402.

Murphy DD, Cole NB, Segal M. Brain-derived neurotrophic factor mediates estradiol-induced dendritic spine formation in hippocampal neurons. Proc Natl Acad Sci USA. 1998; 95:1141211417.

Nahon JL. The melanin-concentrating hormone: from the peptide to the gene. Crit Rev Neurobiol. 1994; 8 (4):221-62. Review.

Nelson RJ, Demas GE, Huang PL, Fishman MC, Dawson VL, Dawson TM, Snyder SH. Behavioural abnormalities in male mice lacking neuronal nitric oxide synthase. Nature. 1995 Nov 23;378(6555):383-6. 
Nemeroff CB, Luttinger D, Prange AJ Jr. Neurotensin and bombesin. In: Handbook of Psychopharmacology. New York: Plenum Press; 1983. v.16; p. 363-466.

Obersteiner, H. The Anatomy of the Nervous Organs in Health and Disease (A. Hill, trans.). London: C. Griffin; 1890.

Patterson SL, Abel T, Deuel TA, Martin KC, Rose JC, Kandel ER. Recombinant BDNF rescues deficits in basal synaptic transmission and hippocampal LTP in BDNF knockout mice. Neuron. 1996; 16:1137:1145.

Pellegri G, Magistretti PJ, Martin JL. VIP and PACAP potentiate the action of glutamate on BDNF expression in mouse cortical neurones. Eur J Neurosci. 1998 Jan;10(1):272-80.

Polan HJ, Hofer MA. Maternally directed orienting behaviors of newborn rats. Dev Psychobiol. 1999 May;34(4):269-79.

Proulx K, Clavel S, Nault G, Richard D, Walker CD. High neonatal leptin exposure enhances brain GR expression and feedback efficacy on the adrenocortical axis of developing rats. Endocrinology. 2001 Nov;142(11):4607-16.

Saper CB. Image is everything. J Comp Neurol. 1999 Sep 27;412(3):381-2.

Schwob JE, Haberly LB, Price JL. The development of physiological responses of the piriform cortex in rats to stimulation of the lateral olfactory tract. J Comp Neurol. 1984 Feb $20 ; 223(2): 223-37$.

Schwob JE, Price JL. The development of axonal connections in the central olfactory system of rats. J Comp Neurol. 1984a Feb 20;223(2):177-202.

Schwob JE, Price JL. The development of lamination of afferent fibers to the olfactory cortex in rats, with additional observations in the adult. J Comp Neurol. 1984b Feb 20;223(2):20322.

Shair HN, Masmela JR, Brunelli SA, Hofer MA. Potentiation and inhibition of ultrasonic vocalization of rat pups: regulation by social cues. Dev Psychobiol. 1997 Apr;30(3):195-200.

Sherwood NT, Lo DC. Long term enhancement of central synaptic transmission by chronic brain-derived neurotrophic factor treatment. J Neurosci. 1999; 19:7025-7036. 
Smith EM and Blalock JE. Human lymphocyte production of corticotropin and endorphin-like substances: association with leukocyte interferon. Proc Natl Acad Sci U S A. 1981 Dec;78(12):7530-4.

Smith GE. The morphology of the indusium and striae lancisii. Anat Anz. 1897; 13:23-27.

Spiess J, Villarreal J, Vale W. Isolation and sequence analysis of a somatostatin-like polypeptide from ovine hypothalamus. Biochemistry. 1981 Mar 31;20(7):1982-8.

Steppan CM, Swick AG. A role for leptin in brain development. Biochem Biophys Res Commun. 1999 Mar 24;256(3):600-2.

Suzuki N, Bekkers JM. Inhibitory interneurons in the piriform cortex. Clin Exp Pharmacol Physiol. 2007 Oct;34(10):1064-9.

Suzuki N, Bekkers JM. Neural coding by two classes of principal cells in the mouse piriform cortex. J Neurosci. 2006; 26(46):11938-47.

Tang Q, Gandhoke R, Burritt A, Hruby VJ, Porreca F, Lai J. High-affinity interaction of (desTyrosyl)dynorphin A(2-17) with NMDA receptors. J Pharmacol Exp Ther. 1999; 291:54-63.

Tang WX, Fasulo WH, Mash DC, Hemby SE. Molecular profiling of midbrain dopamine regions in cocaine overdose victims. J Neurochem. 2003 May;85(4):911-24.

Terman GW, Drake CT, Simmons ML, Milner TA, Chavkin C. Opioid modulation of recurrent excitation in the hippocampal dentate gyrus. J Neurosci. 2000; 20:4379-88.

Terman GW, Wagner JJ, Chavkin C. Kappa opioids inhibit induction of long-term potentiation in the dentate gyrus of the guinea pig hippocampus. J Neurosci. 1994; 14:4740-7.

Thoenen H. Neurotrophins and neuronal plasticity. Science. 1995; 270: 593-598.

Tucker KL, Meyer M, Barde YA. Neurotrophins are required for nerve growth Turing development. Nat Neurosci. 2001; 4:29-37. 
Yokosuka M, Prins GS, Hayashi S. Co-localization of androgen receptor and nitric oxide synthase in the ventral premammillary nucleus of the newborn rat: an immunohistochemical study. Brain Res Dev Brain Res. 1997 Apr 18; 99 (2):226-33.

Wagner JJ, Terman GW, Chavkin. Endogenous dynorphins inhibit excitatory neurotransmission and block LTP inductions in the hippocampus. Nature. 1993; 363:451-4.

Wu B, Hu S, Yang M, Pan H, Zhu S. CART peptide promotes the survival of hippocampal neurons by upregulating brain-derived neurotrophic factor. Biochem Biophy Res Commun. 2006; 347:656-661.

Wyss JM, Sripanidkulchai K. The indusium griseum and anterior hippocampal continuation in the rat. J Comp Neurol. 1983 Sep 20;219(3):251-72.

Zhang Y, Proenca R, Maffei M, Barone M, Leopold L Friedman JM. Positional cloning of the mouse obese gene and its human homologue. Nature. 1994; 372: 425-32. 